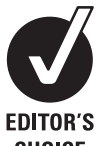

CHOICE

\title{
Inherited mitochondrial optic neuropathies
}

\author{
P Yu-Wai-Man, ${ }^{1,2}$ P G Griffiths, ${ }^{2}$ G Hudson, ${ }^{1}$ P F Chinnery ${ }^{1,3}$
}

\begin{abstract}
${ }^{1}$ Mitochondrial Research Group, The Medical School, Newcastle University, Newcastle upon Tyne, UK; ${ }^{2}$ Department of Ophthalmology, Royal Victoria Infirmary, Newcastle upon Tyne, UK; ${ }^{3}$ Institute of Human Genetics, Newcastle University, Newcastle upon Tyne, NE1 3BZ, UK
\end{abstract}

Correspondence to: Professor P F Chinnery, Mitochondrial Research Group, The Medical School, Newcastle University, Newcastle upon Tyne, NE2 4HH, UK; P.F. Chinnery@ncl.ac.uk

Received 8 September 2008 Revised 8 September 2008 Accepted 7 October 2008 Published Online First 17 November 2008

\section{ABSTRACT}

Leber hereditary optic neuropathy (LHON) and autosomal dominant optic atrophy (DOA) are the two most common inherited optic neuropathies and they result in significant visual morbidity among young adults. Both disorders are the result of mitochondrial dysfunction: LHON from primary mitochondrial DNA (mtDNA) mutations affecting the respiratory chain complexes; and the majority of DOA families have mutations in the OPA1 gene, which codes for an inner mitochondrial membrane protein critical for mtDNA maintenance and oxidative phosphorylation. Additional genetic and environmental factors modulate the penetrance of LHON, and the same is likely to be the case for DOA which has a markedly variable clinical phenotype. The selective vulnerability of retinal ganglion cells (RGCs) is a key pathological feature and understanding the fundamental mechanisms that underlie RGC loss in these disorders is a prerequisite for the development of effective therapeutic strategies which are currently limited.

Mitochondrial disorders are a major cause of chronic human disease with an estimated prevalence of 1 in 10000 in the UK and a further 1 in 200 individuals being at-risk mutational carriers. ${ }^{12}$ Ocular involvement is a prominent feature in this group and often points towards the underlying mitochondrial aetiology, which allows for a more targeted diagnostic approach. Optic nerve dysfunction can be the presenting and only ophthalmological manifestation causing the two most common inherited optic neuropathies encountered in clinical practice, Leber hereditary optic neuropathy (LHON) and autosomal dominant optic atrophy (DOA), which are the focus of this review. In the majority of cases, the pathology in LHON and DOA is limited to a highly specialised group of cells within the eye, the retinal ganglion cells (RGCs), but the phenotype associated with these two conditions is expanding, providing important insights into possible disease pathways leading to optic nerve degeneration and visual failure.

\section{LEBER HEREDITARY OPTIC NEUROPATHY LHON mutations}

LHON (OMIM 535000) was first described as a distinctive clinical entity in 1871 by the German ophthalmologist Theodore Leber (1840-1917). ${ }^{3} \mathrm{He}$ reported a characteristic pattern of visual loss among members of four families and his observations were subsequently confirmed in pedigrees from different populations. ${ }^{4-6}$ These early studies highlighted several of the salient features of LHON including the maternal transmission of the disease, the predilection of males to lose vision, and the almost exclusive involvement of the optic nerve. The non-Mendelian pattern of inheritance was only fully explained in 1988 when LHON became the first human disease proven to be caused by a point mutation (m.11778G $>$ A) within the mitochondrial genome. ${ }^{7}$ Over $95 \%$ of $\mathrm{LHON}$ pedigrees are now known to harbour one of three mitochondrial DNA (mtDNA) point mutations: m.3460G $>$ A, m.11778G $>A$ and m.14484T $>C$, which all involve genes encoding complex I subunits of the mitochondrial respiratory chain. ${ }^{8}$ In a meta-analysis of 159 pedigrees from Northern Europe and Australia, m.11778G $>$ A was the most prevalent mutation but there is considerable variation in the relative frequency of these three primary LHON mutations worldwide (table 1). The predominance of $\mathrm{m} .11778 \mathrm{G}>\mathrm{A}$ is even more pronounced in the Far East where it accounts for $\sim 90 \%$ of all cases, ${ }^{910}$ and although $\mathrm{m} .14484 \mathrm{~T}>\mathrm{C}$ is relatively rare, it is the most common mutation found among French Canadians (87\%) as a result of a founder event. ${ }^{11}{ }^{12}$ Primary mutations have not been identified in a small minority of clinically diagnosed LHON patients, the most likely explanation being that rare pathogenic mtDNA variants are segregating in these families. ${ }^{13}$ Disease causing mutations have been identified in a proportion of these cases, while other putative LHON mutations require further confirmation as they have only been found in singletons or a single family (table 1).

\section{Epidemiology}

$\mathrm{LHON}$ is the most common of the primary mtDNA diseases, with a minimum prevalence of 1 in 31000 affected individuals in the North East of England and 1 in 8500 carriers being at-risk of visual loss. ${ }^{14}$ Fairly similar figures have been reported in other Caucasian populations, with an LHON prevalence of 1 in 39000 in the Netherlands and 1 in 50000 in Finland. ${ }^{15}{ }^{16}$ About 2\% of visually impaired people on the blind register in Australia are also reported to suffer from LHON. ${ }^{17}$ The peak age of onset in LHON is between the age of 1530 years and $95 \%$ of carriers who will experience visual failure will do so before the age of 50 years (table 2). However, visual deterioration can occur anytime during the first to the seventh decade of life and LHON should be part of the differential diagnosis for all cases of bilateral, simultaneous or sequential optic neuropathy, irrespective of age and especially in male patients. ${ }^{19}$ Except for one report which found a slight increase in the age of onset in females carrying the m.11778G $>$ A mutation, ${ }^{20}$ it is generally accepted that neither gender nor mutational status significantly influences the timing and severity of the initial visual loss. ${ }^{11}{ }^{21-23}$ Affected individuals are often aware of other affected family members, but up to $40 \%$ have no family history. These most likely represent cases online under the BMJ Journals unlocked scheme, see http:// jmg.bmi.com/info/unlocked.dtl 
Table 1 Pathogenic mtDNA mutations associated with Leber hereditary optic neuropathy

\begin{tabular}{|c|c|c|c|c|}
\hline & Mutation & Gene & Prevalence (\%) & Reference \\
\hline \multirow[t]{4}{*}{ Primary } & & & $>95$ & \\
\hline & m. $3460 \mathrm{G}>\mathrm{A}$ & $M T-N D 1$ & 13 & 220,221 \\
\hline & m.11778G $>A$ & $M T-N D 4$ & 69 & 7 \\
\hline & $\mathrm{m} \cdot 14484 \mathrm{~T}>\mathrm{C}$ & MT-ND6 & 14 & 32,222 \\
\hline \multirow[t]{19}{*}{ Rare } & & & $<5$ & \\
\hline & m. $3376 \mathrm{G}>\mathrm{A}$ & $M T-N D 1$ & & 45 \\
\hline & m. $3697 \mathrm{G}>\mathrm{A}$ & & & 46 \\
\hline & m. $3733 \mathrm{G}>\mathrm{A}$ & & & 223 \\
\hline & $\mathrm{m} .4160 \mathrm{~T}>\mathrm{C}$ & & & 41 \\
\hline & $\mathrm{m} .4171 \mathrm{C}>\mathrm{A}$ & & & 224 \\
\hline & m.11696G $>A$ & $M T-N D 4$ & & 40 \\
\hline & $\mathrm{m} .11253 \mathrm{~T}>\mathrm{C}$ & & & 225 \\
\hline & m.10663T $>C$ & $M T-N D 4 L$ & & 226 \\
\hline & $\mathrm{m} .12848 \mathrm{C}>\mathrm{T}$ & MT-ND5 & & 227 \\
\hline & m. $13730 \mathrm{G}>\mathrm{A}$ & & & 228 \\
\hline & $\mathrm{m} .14568 \mathrm{C}>\mathrm{T}$ & $M T-N D 6$ & & 229 \\
\hline & m. $14279 \mathrm{G}>\mathrm{A}$ & & & 230 \\
\hline & m. $14459 \mathrm{G}>\mathrm{A}$ & & & $42-44$ \\
\hline & $\mathrm{m} \cdot 14482 \mathrm{C}>\mathrm{G}$ & & & 231 \\
\hline & m. $14495 A>G$ & & & 232 \\
\hline & $\mathrm{m} \cdot 14498 \mathrm{C}>\mathrm{T}$ & & & 233 \\
\hline & $\mathrm{m} .14568 \mathrm{C}>\mathrm{T}$ & & & 234 \\
\hline & m.14596A $>T$ & & & 40 \\
\hline
\end{tabular}

where family history is difficult to trace back, given that de novo mutations are rare in LHON. ${ }^{14} 24$

\section{Clinical features}

\section{Pre-symptomatic phase}

Fundal abnormalities such as telangiectatic vessels around the optic discs and variable degrees of retinal nerve fibre layer oedema have been documented in some asymptomatic carriers, and these can fluctuate with time. Using optical coherence tomography imaging, thickening of the temporal retinal nerve fibre layer was found in a proportion of unaffected LHON carriers, which provides further evidence that the papillomacular bundle is particularly vulnerable in this disorder. ${ }^{25}{ }^{26} \mathrm{On}$ more detailed psychophysical testing, some individuals also exhibited subtle impairment of optic nerve function including loss of colour vision affecting mostly the red-green system, reduced contrast sensitivity, and subnormal visual electrophysiological parameters. ${ }^{27}$

\section{Acute phase}

LHON carriers remain asymptomatic until they experience blurring or clouding of vision in one eye. In the vast majority of

Table 2 Lifetime risk of visual failure for Leber hereditary optic neuropathy carriers and recovery rates

\begin{tabular}{llllll}
\hline & $\begin{array}{l}\text { Pedigrees } \\
(\mathbf{n})\end{array}$ & $\begin{array}{l}\text { Median } \\
\text { onset }\end{array}$ & $\begin{array}{l}\text { Male: } \\
\text { female } \\
\text { ratio }\end{array}$ & $\begin{array}{l}\text { Visual } \\
\text { recovery } \\
(\%)\end{array}$ & Reference \\
\hline m.3460G $>$ A & 9 & 29 years & $2.3: 1$ & 22 & 22 \\
& 8 & 20 years & $4.3: 1$ & 25 & 20 \\
m.11778G $>$ A & 49 & 28 years & $4.5: 1$ & 4 & 21 \\
& 66 & 24 years & $3.7: 1$ & 25 & 20 \\
m.14484T $>$ C & 10 & 29 years & $5.3: 1$ & 25 & 28 \\
& 17 & 27 years & $2.1: 1$ & 37 & 23 \\
& 23 & 19 years & $7.7: 1$ & 58 & 11 \\
\hline
\end{tabular}

cases, visual dysfunction is bilateral, the fellow eye becoming affected either simultaneously (25\%) or sequentially $(75 \%)$, with a median inter-eye delay of 6-8 weeks. ${ }^{20}$ Rare cases of unilateral optic neuropathy in LHON have been reported, with the fellow eye remaining unaffected over a follow-up period of up to 16 years. ${ }^{28}{ }^{29}$ Visual acuity reaches a nadir 4-6 weeks after disease onset and it is severely reduced to $6 / 60$ or less. The characteristic field defect is a steep-sided central or centrocaecal scotoma and this can be formally documented using Goldmann or kinetic perimetry. Other clinical features include the early impairment of colour perception but, importantly, pupillary reflexes are preserved and patients usually report no pain on eye movement. Ocular examination during the acute stage provides other diagnostic clues and in classical cases the following abnormalities can be observed: vascular tortuosity of the central retinal vessels, swelling of the retinal nerve fibre layer, and a circumpapillary telangiectatic microangiopathy (fig 1). However, it must be stressed that in $~ 20 \%$ of LHON cases, the optic disc looks entirely normal in the acute phase. ${ }^{30} 31$

\section{Chronic phase}

The retinal nerve fibre layer gradually degenerates and after 6 months, optic atrophy is a universal feature. If a patient is only seen at this stage, it can be difficult to exclude other compressive, infiltrative and inflammatory causes of a bilateral optic neuropathy, especially if there is no clear maternal family history. In these cases, neuroimaging of the anterior visual pathways is mandatory while awaiting the results of molecular genetic testing.

\section{Visual recovery}

Visual recovery is observed in some patients even several years following disease onset. but the chances of improvement are influenced by the patient's mutational status, being least with the m.11778G $>$ A mutation, highest with the m.14484T $>C$ mutation, and the m.3460G $>$ A mutation having an intermediate visual prognosis (table 2 ). The recovery in visual parameters is not only restricted to visual acuity, but can also include the development of small islands of normal field (fenestrations) within the central scotoma or a reversal of dyschromatopsia. ${ }^{28} 3233$ Positive prognostic factors for visual improvement are

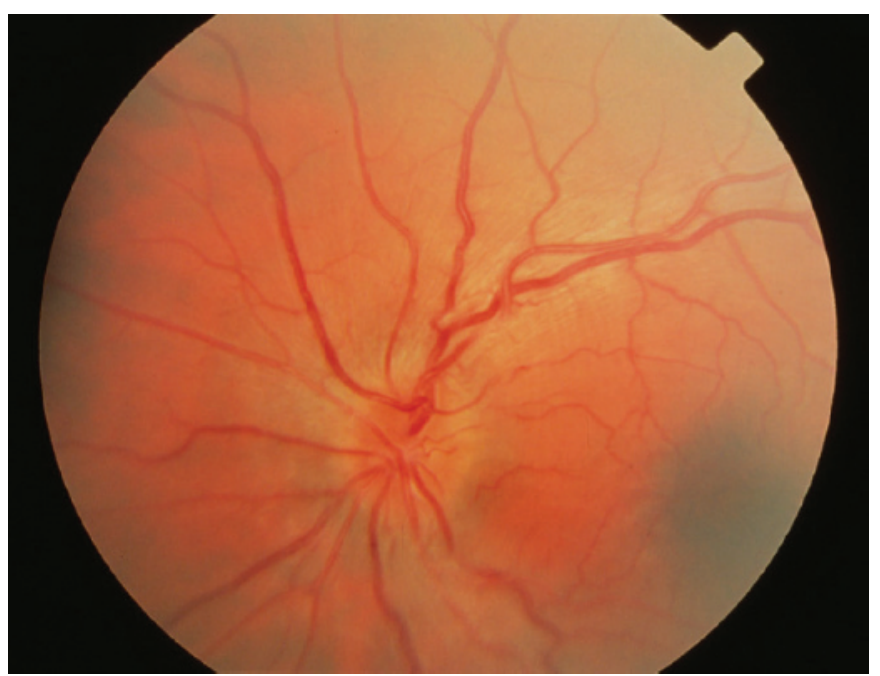

Figure 1 Acute fundal appearance in Leber hereditary optic neuropathy showing disc hyperaemia, swelling of the parapapillary retinal nerve fibre layer and retinal vascular tortuosity. 
an early age of onset ( $<20$ years), subacute presentation with slow progression of the visual deficits, and large optic nerve head surface area. ${ }^{28}{ }^{34}$ However, LHON is a devastating disorder with the majority of patients showing no functional improvement and remaining within the legal requirement for blind registration.

\section{Associated features}

Although visual failure is the defining feature in this mitochondrial disorder, cardiac arrhythmias and neurological abnormalities such as postural tremor, peripheral neuropathy, nonspecific myopathy and movement disorders have been reported to be more common in LHON compared to controls. ${ }^{35-39}$ These are rarely clinically significant but a small number of LHON pedigrees do have severe neurological deficits (spastic dystonia, ataxia and juvenile onset encephalopathy) in addition to the optic neuropathy. These "LHON plus" syndromes have been linked to various mtDNA mutations in isolated pedigrees from Holland, Australia and North America: A11696G and/or T14596A, ${ }^{40} \mathrm{~T}_{4160 \mathrm{C}}{ }^{41}$ and $\mathrm{G} 14459 \mathrm{~A},{ }^{42-44}$ respectively. Two mtDNA complex I mutations point mutations, m.3376G $>\mathrm{A}^{45}$ and $\mathrm{m} .3697 \mathrm{G}>\mathrm{A},{ }^{46}$ have also recently been identified in individuals with overlap clinical features of both LHON and MELAS (mitochondrial encephalomyopathy, lactic acidosis, and stroke-like episodes). Interestingly, a significant minority of Caucasian LHON carriers, predominantly females with the m.11778G $>$ A mutation, develop clinical and neuroimaging features indistinguishable from multiple sclerosis (MS), including unmatched oligoclonal bands in the cerebrospinal fluid (Harding's disease). ${ }^{47-50}$ It is currently not known whether the prevalence of this MS-like illness in LHON is higher than expected due to the chance occurrence of these two disorders, and although controversial, some investigators have argued for a potential role of autoimmunity in the pathophysiology of this mitochondrial disorder. ${ }^{51-55}$

\section{Diagnosis}

A tentative diagnosis of LHON can usually be made on clinical grounds, especially if classical ophthalmological features are present and a clear maternal history is elicited. Molecular genetic testing on a blood DNA sample, however, remains the gold standard and will confirm that the patient harbours one of the three primary mtDNA LHON mutations, with implications for future genetic counselling. If indicated, electrophysiological studies, including pattern electroretinograms (PERGs) and visual evoked potentials (VEPs), can be carried out to exclude retinal pathology and confirm optic nerve dysfunction. ${ }^{56}$ An electrocardiogram is also recommended to exclude a preexcitation syndrome which has been documented in LHON, although such a finding is rare and does not require any intervention in the absence of cardiac symptoms. ${ }^{30}{ }^{31}$ Computed

Table 3 Respiratory chain dysfunction in Leber hereditary optic neuropathy

\begin{tabular}{|c|c|c|c|c|}
\hline \multirow[b]{2}{*}{$\begin{array}{l}\text { MtDNA } \\
\text { mutation }\end{array}$} & \multicolumn{3}{|c|}{ In vitro ${ }^{88} 235-249$} & \multirow{2}{*}{$\begin{array}{l}\text { In vivo }{ }^{63-67} \\
{ }^{31} \mathrm{P} \text { MRS (\%) }\end{array}$} \\
\hline & $\begin{array}{l}\text { Complex I } \\
\text { activity (\%) }\end{array}$ & $\begin{array}{l}\text { Respiratory } \\
\text { rate }(\%)\end{array}$ & $\begin{array}{l}\text { ATP synthesis } \\
(\%)\end{array}$ & \\
\hline $\mathrm{m} .3460 \mathrm{G}>\mathrm{A}$ & $60-80$ & $30-35$ & 90 & $0-40$ \\
\hline $\mathrm{m} .11778 \mathrm{G}>\mathrm{A}$ & $0-50$ & $30-50$ & 35 & 75 \\
\hline m.14484T $>C$ & $0-65$ & $10-20$ & 90 & 50 \\
\hline
\end{tabular}

ATP, adenosine triphosphate; ${ }^{31} \mathrm{P}-\mathrm{MRS}$, phosphorus magnetic resonance spectroscopy.

$\%$ decrease relative to controls. tomography (CT) and magnetic resonance imaging (MRI) scans are usually normal in LHON, but there are reports of nonenhancing high signals within the optic nerve and sheath distension, secondary to slight oedema or gliosis in the atrophic phase. $^{57-62}$

\section{Biochemical features}

Oxidative phosphorylation (OXPHOS) provides for most of the cell's adenosine triphosphate (ATP) requirements and this is achieved by a chain of five respiratory complexes situated on the inner mitochondrial membrane. Since all three primary LHON mutations involve complex I subunits, one would expect respiratory chain function to be compromised, leading to a deficit in ATP synthesis and RGC degeneration as a consequence of energy failure. However, both in vitro and in vivo biochemical studies have produced conflicting results regarding the extent of respiratory chain dysfunction in LHON (table 3). In a small number of in vivo studies using phosphorus magnetic resonance spectroscopy ( $\left({ }^{31} \mathrm{P}-\mathrm{MRS}\right)$, the most consistent defect of mitochondrial function was identified in persons with the m.11778G $>A$ mutation and none among those with the m.3460G $>$ A mutation. ${ }^{6-67}$ A striking conclusion from all these biochemical studies is that no significant difference between affected and unaffected individuals with a disease causing LHON mutation could be demonstrated. But as none of these studies have been performed directly on RGCs and the causative biochemical mechanisms could be highly tissue-specific, further studies are warranted.

\section{Neuropathology}

These functional studies also raise important issues regarding the cell specific ocular pathology in LHON which is limited to the RGC layer, with sparing of the retinal pigment epithelium and photoreceptors. There is pronounced cell body and axonal degeneration, with associated demyelination and atrophy observed from the optic nerves to the lateral geniculate bodies. Experimental data indicate impaired glutamate transport, ${ }^{68}$ oxidative stress ${ }^{69} 70$ and increased mitochondrial reactive oxygen species $(R O S)^{71}$ within RGCs and support an apoptotic mechanism of cell death. ${ }^{72}{ }^{73} \mathrm{LHON}$ patients also have reduced $\alpha$-tocopherol/lipid ratios and high levels of 8-hydroxy-2-deoxygaunosine in blood leucocytes, both biological markers of increased free radical production. ${ }^{745}$ However, the selective vulnerability of RGCs in LHON still remains unexplained, and this area of research has been greatly hampered by the lack of access to diseased human tissues, the retina and optic nerve not being amenable to biopsies.

\section{Animal models}

The development of faithful animal models in LHON is therefore critical but there is still no murine model where the primary LHON mutations have been successfully introduced within the mitochondrial genome. In spite of these technical challenges, significant advances have been made over the past decade and there are currently three experimental paradigms, all of which disrupt OXPHOS and recapitulate the optic nerve degeneration seen in LHON: (1) intravitreal injection of a respiratory chain poison such as rotenone ${ }^{76}$; (2) downregulation of nuclear encoded complex I subunits (for example, NFUFA1) with specific mRNA-degrading ribozymes ${ }^{77}$; and (3) allotropic expression of mutant subunits (for example, MTND4) which are then imported into the mitochondria. ${ }^{78}$ 
Figure 2 Secondary factors interacting with the primary mtDNA Leber hereditary optic neuropathy mutation to precipitate visual loss. ATP, adenosine triphosphate; ROS, reactive oxygen species.

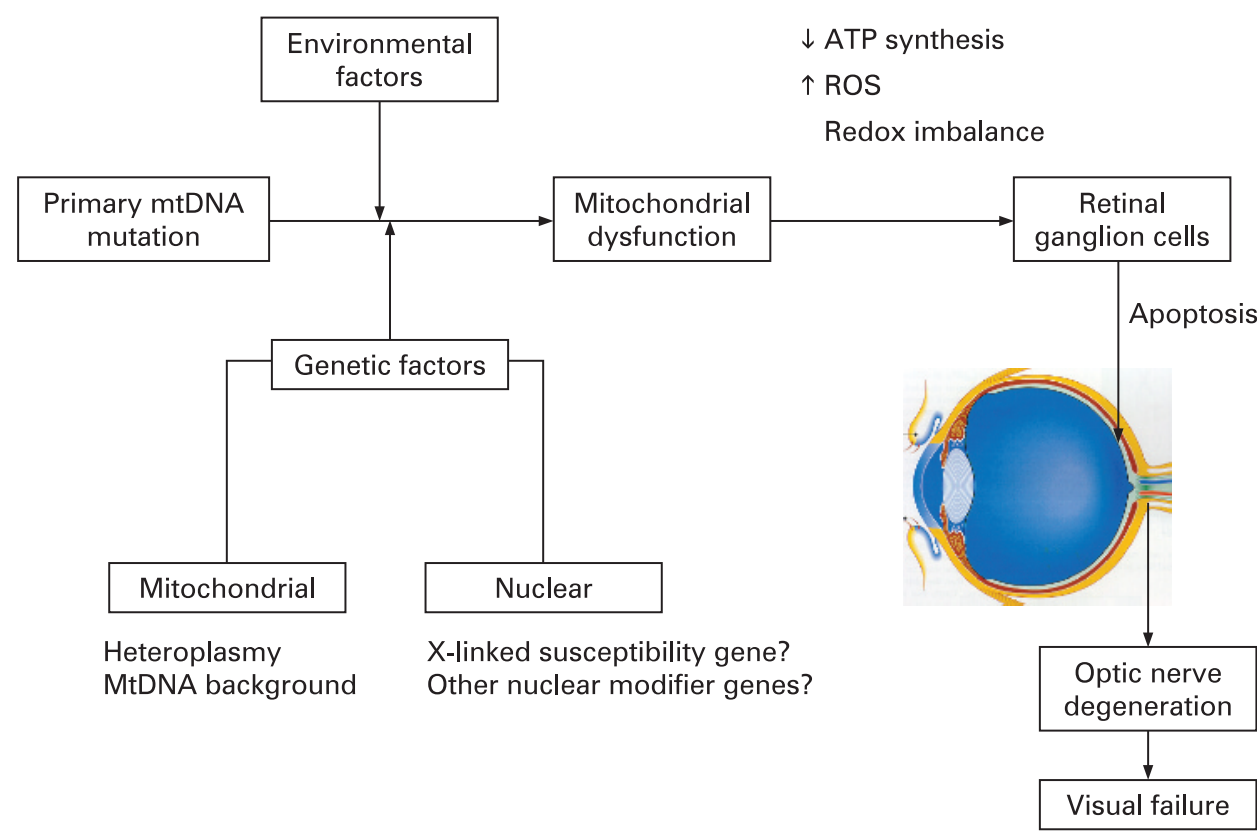

A recent meta-analysis of 159 European LHON pedigrees indicated that the risk of visual loss for the three primary LHON mutations is influenced by the mtDNA background. ${ }^{85}$ The risk of visual failure was greater when the $\mathrm{m} .11778 \mathrm{G}>\mathrm{A}$ and $\mathrm{m} .14484 \mathrm{~T}>\mathrm{C}$ mutations arose on haplogroup J, whereas individuals with the m.3460G $>$ A mutation were more likely to experience visual loss if they belonged to haplogroup $\mathrm{K}$. On the other hand, individuals with the m.11778G $>$ A mutation had a lower risk of visual loss when the mutation arose on haplogroup $\mathrm{H}$. Haplogroups $\mathrm{H}$, J and $\mathrm{K}$ are all defined by non-synonymous, polymorphic substitutions in the MT-CYB gene which codes for cytochrome $b$, the only mitochondrially encoded subunit of complex III. Recent experimental data support the existence of stable respiratory chain supercomplexes, one of which consists of a complex I monomer physically interacting with a complex III dimer. Although speculative, the haplogroup associated amino acid substitutions within cytochrome $b$ could therefore influence the risk of visual failure by modulating the biochemical consequences of the primary LHON mutations through an effect on the stability of these putative I-III supercomplexes. ${ }^{85-87}$ In support of this hypothesis, cybrid cell lines carrying the m.11778AG > A mutation on a haplogroup J background had a lower oxygen consumption and a longer doubling time compared to non-haplogroup J cell lines. ${ }^{88}$ However, haplogroup $\mathrm{J}$ was not found to further impair mitochondrial OXPHOS in the brain and skeletal muscle of patients harbouring the m.11778G > A mutation with ${ }^{31} \mathrm{P}-\mathrm{MRS}$ measurements, ${ }^{66}$ and a study of South-East Asian LHON pedigrees found no association between specific mtDNA haplogroups and the risk of visual loss. $^{89}$ These contradictory findings reflect the need for additional studies to clarify the significance of the mtDNA background on LHON penetrance.

\section{Nuclear genetic factors}

The predominance of affected males in LHON cannot be explained by mitochondrial inheritance and segregation analysis suggests the existence of a recessive $\mathrm{X}$-linked susceptibility gene acting in synergy with the mtDNA mutation to precipitate the optic neuropathy. ${ }^{90-92}$ In the $B u$ and Rotter model, the variants cluster together in specific combinations referred to as haplogroups, with individuals of European ancestry belonging to one of nine haplogroups: $\mathrm{H}, \mathrm{I}, \mathrm{J}, \mathrm{K}, \mathrm{T}, \mathrm{U}, \mathrm{V}, \mathrm{W}$ and $\mathrm{X} .{ }^{83}{ }^{84}$ 
development of blindness in males is consistent with the simultaneous inheritance of an X-linked visual loss allele and the primary LHON mutation, whereas females are affected either if they are homozygous at the susceptibility locus (40\%) or heterozygous with skewed X chromosome inactivation of the wild-type allele (60\%). Several studies have, however, failed to demonstrate any skewed X chromosome inactivation in affected female carriers, albeit in blood leucocytes and not in RGCs which are the affected tissues in LHON. ${ }^{93-95}$ Initial attempts to identify this X-linked susceptibility locus by standard linkage analysis were unsuccessful, ${ }^{96-99}$ but two recent studies using a larger number of more extensively defined LHON pedigrees found two overlapping disease loci with highly significant LOD scores at Xp21-Xq21 ${ }^{100}$ and Xq25-27.2. ${ }^{101}$ Although the actual causative gene in this region of interest has not yet been identified, a high risk haplotype [DXS8090(166)-DXS1068(268)] at Xp21 was defined which increased the risk of visual failure $\sim 35$-fold for the $\mathrm{m} .11778 \mathrm{G}>\mathrm{A}$ and $\mathrm{m} 14484 \mathrm{~T}>\mathrm{C}$ mutations but not for m.3460G $>$ A. ${ }^{100}$ The possibility of other autosomal nuclear modifier genes in LHON has not been excluded and the genetic aetiology of LHON might prove even more complex, with epistatic interaction of these multiple nuclear susceptibility loci and genetic heterogeneity.

\section{Environmental factors}

Five pairs of monozygotic twins harbouring a primary LHON mutation have been reported in the literature, and in two cases the twins have remained discordant. ${ }^{20} 21^{24}{ }^{102-104}$ Although there is always the possibility that the unaffected sibling will lose vision later on in life, the existence of discordant monozygotic twins strongly suggests that environmental factors also contribute to penetrance. There are several reports of an increased risk of visual loss among LHON carriers with high tobacco and alcohol consumption, ${ }^{105-108}$ but the largest casecontrol study to date has failed to confirm this association. ${ }^{109}$ There are also anecdotal reports of nutritional deprivation, exposure to industrial toxins, antiretroviral drugs, psychological stress or acute illness precipitating the onset of blindness in LHON. ${ }^{108}{ }^{110-112}$ Of note, in some pedigrees the penetrance of LHON seems to be decreasing, falling to $1 \%$ and $9 \%$ in younger generations of two large, multi-generational pedigrees from Australia ${ }^{113}$ and Brazil, ${ }^{108}{ }^{114}$ respectively. Both carry homoplasmic levels of the m.11778G $>$ A mutation and this phenomenon has been ascribed to improved environmental and socioeconomic factors. However, a much larger epidemiological study of 3613 LHON carriers from multi-generational pedigrees failed to detect a change in the penetrance of the three primary LHON mutations. The role of environmental triggers in LHON remains largely unanswered and more robust epidemiological data are needed, which will necessitate a multicentre collaborative effort in order to collect sufficient number of subjects for analysis.

\section{Treatment}

No generally accepted measures have been shown to either prevent or delay the onset of blindness in LHON, but for general health reasons LHON carriers should be advised to moderate their alcohol intake and stop smoking. In two small case series, oral administration of idebenone, a synthetic analogue of coenzyme Q10, and vitamin B12 and C supplementation led to faster and greater visual recovery among affected individuals. ${ }^{115} 116$ However, a recent study has not found any improved visual prognosis from idebenone and multivitamin supplementation, and properly conducted treatment trials are needed before such a regimen can be advocated. ${ }^{117}$ The use of brimonidine eye drops, which is thought to have anti-apoptotic properties, was also unsuccessful in preventing second eye involvement in recently affected patients with unilateral optic neuropathy. ${ }^{118}$ The long term management of visually impaired patients remains supportive, with provision of visual aids and registration with the relevant social services.

\section{Genetic counselling}

It is important to stress to $\mathrm{LHON}$ carriers that it is not possible to predict accurately whether or when they will become affected. Despite these caveats, the two main predictive factors for visual failure remain age and gender, with males having about a $50 \%$ lifetime risk of blindness compared to only $10 \%$ for females, and these approximate figures can be further refined based upon the patient's age. From published age dependent penetrance data, most patients experience visual loss in their late teens and 20 s and the probability of becoming affected decreases with increasing age, being minimal once past the age of 50 years (table 2). Once a primary LHON mutation has been identified in a proband, other maternally related family members can be offered molecular genetic testing to exclude the possibility of a de novo mutation, which is rare. Since LHON shows strict maternal inheritance, male carriers can be reassured that none of their children will inherit the mtDNA mutation whereas female carriers will transmit the pathogenic mutation to all of their offspring. Since most mothers are homoplasmic, their children will only harbour the mutant species, but the situation is more complex for a heteroplasmic mother as she could transmit a higher or a lower level of the mutation to a particular offspring, which will impact on the latter's risk of visual failure. Although the mutant level can be determined and there is evidence that a mutational threshold of $\sim 60 \%$ in blood is necessary for disease expression, genetic counselling for these unaffected heteroplasmic carriers remains difficult. For similar reasons, the prenatal genetic testing of heteroplasmic women with amniocentesis or chorionic villus sampling (CVS) would be difficult to interpret.

\section{DOMINANT OPTIC ATROPHY \\ Clinical features}

The clinical features of DOA (OMIM 165500) were first described in one British family by Batten in 1896 $119{ }^{120}$; the phenotype was further clarified by Kjer in his extensive study of Dutch families in the 1950s, ${ }^{119}{ }^{120}$ distinguishing it from LHON with which the disease was often confused. The prevalence of DOA is not well established and robust estimates based on molecular confirmation are not available, although a historical figure of 1 in 50000 among Caucasians is often quoted in the literature. ${ }^{121}$ It is thought to be the most common inherited optic neuropathy in the Netherlands, with a population frequency of 1 in 12 000, and this much higher prevalence has been linked to a mutational founder event. ${ }^{122}$

The onset of symptoms in DOA is relatively insidious. In premolecular case series, $13-25 \%$ of patients with optic atrophy were visually asymptomatic and were only identified through contact tracing via other affected family members. ${ }^{123} 124$ Classically, the visual decline starts in the first two decades of life, but there is a pronounced inter- and intra-familial variability in the severity of visual symptoms, which makes genetic counselling difficult. Visual acuity can range from $6 / 6$ to the detection of hand movement only, and the rate of 
progression of visual loss is not easy to predict, with $19-50 \%$ of patients experiencing further, albeit slow, deterioration on long term follow up. ${ }^{125-129}$ Although the overall visual prognosis is better when compared to LHON, with a mean visual acuity of 6/24-6/36, DOA results in significant visual impairment with about half of all affected individuals failing the driving standards and $13-46 \%$ registered as legally blind. ${ }^{130-132}$

The predominant colour defect in DOA is a generalised dyschromatopsia, involving both the blue-yellow and red-green axes, with a minority of patients having pure tritanopia $(<10 \%)$, which was once considered to be a pathognomonic feature of DOA. ${ }^{133}$ Central, centrocaecal and paracentral scotomas are the most common field abnormalities with sparing of the periphery, findings consistent with the primary involvement of the papillomacular bundle in this condition. Interestingly, as in LHON, there is usually no afferent pupillary defect, suggesting that the retino-tectal fibres sub-serving the pupillary light reflex are less susceptible to the downstream effects of both the LHON mtDNA mutations and the causative nuclear genetic defects in DOA. ${ }^{134}$ However, both magnocellular and parvocellular RGC pathways seem to be similarly affected, although this requires further investigation. ${ }^{127} 131$

The optic disc pallor in DOA falls into two main categories: diffuse pallor involving the entire neuro-retinal rim in about half of all cases, and a temporal wedge in the remainder (fig 3). ${ }^{123} 135$ However, disc pallor can be subtle and $29 \%$ of affected patients had normal looking optic discs in one case series, highlighting the need to look carefully for other features of optic nerve dysfunction when assessing patients with a possible diagnosis of DOA. ${ }^{132}$ Other common optic disc findings include saucerisation $(79 \%)$, peripapillary atrophy $(69 \%)$ and a cup to disc ratio $>0.5$ (48\%). ${ }^{131} 135136$ The measurement of circumpapillary retinal nerve fibre layer thickness using optical coherence tomography (OCT) could also prove a useful adjunct in the diagnostic workup of DOA, with recent studies showing a typical profile with bilateral symmetrical thinning around the optic disc, most pronounced in the temporal quadrant. ${ }^{137} 138$

\section{Ocular pathology}

Postmortem studies of two patients with DOA identified similar histopathological changes, with diffuse atrophy of the RGC layer, loss of myelin and fibrillary gliosis along the anterior visual pathways extending to the lateral geniculate body. ${ }^{139} 140$ More recent MRI data from patients with DOA have also confirmed significant tissue loss and thinning of the optic nerve along its entire length. ${ }^{141}$ Although less pronounced, the underlying ocular pathology in DOA is therefore remarkably similar to LHON, with the primary loss of RGCs leading to ascending optic atrophy.

Visual electrophysiological findings are well documented in $\mathrm{DOA}$ and provide additional evidence for the primary loss of RGCs and the sparing of the outer retinal layers. ${ }^{133}{ }^{142}{ }^{143}$ It can therefore be a useful ancillary test when determining affected status in borderline DOA cases and also in excluding a primary retinal process such as early cone dystrophy. VEPs are either absent or, if traces are recordable, they are of low amplitudes with abnormal latencies. PERGs can be within the normal range in up to $40 \%$ of clinically affected individuals but usually demonstrate an abnormal P50:N95 ratio, with selective depression of the N95 negative wave amplitude confirming a primary optic nerve pathology. Additional involvement of the P50 component correlates with the severity of visual loss, but PERGs are not extinguished even in cases where visual acuity is reduced to detection of hand movements or worse.

\section{Molecular genetics}

The majority of DOA families show linkage to the OPA1 locus at 3q28-q29, and in 2000 two independent research groups identified pathogenic mutations in the OPA1 gene. ${ }^{144} 145$ The proportion of OPA1 positive families is $\sim 60 \%$ (range $32-89 \%$ ), the lower detection rates in some of these case series reflecting the inclusion of singleton cases, a heterogeneous group that is more likely to include non-inherited forms of optic neuropathy, and the use of less sensitive mutation screening protocols such as single strand conformational polymorphism (SSCP) analysis. ${ }^{146} 147$ Interestingly, a recent report suggested that large scale rearrangements of entire OPA1 coding regions could account for up to $20 \%$ of all OPA1 negative cases. ${ }^{148}$

The causative nuclear defects in the remaining families with DOA have not yet been identified, but a small number of families have been mapped to other chromosomal loci-OPA3, OPA4, OPA5 and OPA7, of which only the OPA3 gene has been characterised (table 4). The OPA3 gene was originally identified in eight Iraqi Jewish families with an autosomal recessive form of optic atrophy, associated with neurocognitive deficits, elevated urinary excretion of 3-methyl glutaconic acid, and increased plasma 3-methylglutaric acid levels (type III 3methylglutaconic aciduria or Costeff syndrome). ${ }^{149-151}$ However, pathogenic mutations in the OPA3 gene have also been identified in two French families segregating both DOA and premature cataract in an autosomal dominant mode of inheritance (ADOAC). ${ }^{152} 153$ The Opa3 protein is located in the
Figure 3 Typical fundal appearance in dominant optic atrophy showing bilateral optic disc pallor more marked in the temporal quadrant (LE, left eye; $\mathrm{RE}$, right eye; T, temporal quadrant).
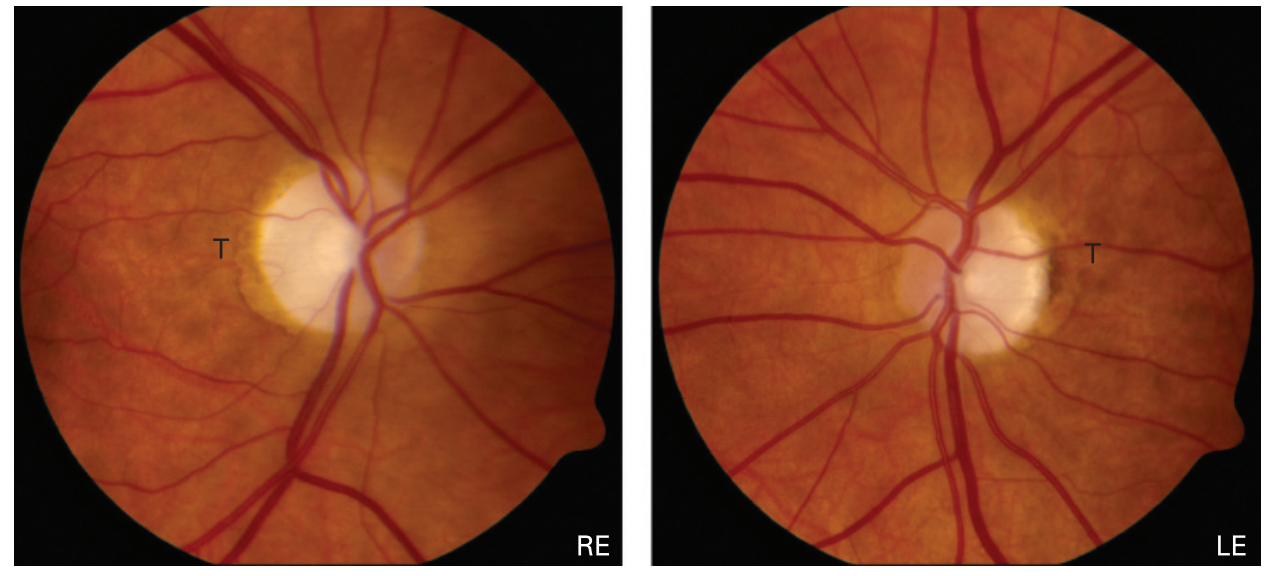
Table 4 Dominant optic atrophy loci reported in OPA1 negative families

\begin{tabular}{lllllll}
\hline & OMIM & Reported locus & $\begin{array}{l}\text { Causative } \\
\text { gene }\end{array}$ & Families $(\mathbf{n})$ & Clinical features & Reference \\
\hline OPA-3 & 606580 & $19 q 13.2-q 13.3$ & OPA3 & 2 & Optic atrophy + premature cataract & 152 \\
OPA-4 & 605293 & $18 q 12.2-q 12.3$ & Unknown & 1 & Optic atrophy* & 250 \\
OPA-5 & 610708 & $22 q 12.1-q 13.1$ & Unknown & 2 & Optic atrophy* & 251 \\
OPA-7 & - & $16 q 21-q 22$ & Unknown & 1 & Optic atrophy + deafness & 252 \\
\hline
\end{tabular}

${ }^{*}$ Similar clinical phenotype to OPA1 positive families.

mitochondrial inner membrane but its exact function remains to be clarified. Preliminary findings in cultured fibroblasts from a patient with $\mathrm{ADOAC}$ indicate an increased susceptibility to apoptosis, and one can speculate that a similar mechanism is leading to RGC dysfunction via disruption of the mitochondrial respiratory chain..$^{152} 154155$

\section{OPA1 mutations}

The OPA1 gene consists of 30 exons spanning over $100 \mathrm{~Kb}$ of genomic DNA and it codes for a 960 amino acid, dynamin related GTPase protein located within the inner mitochondrial membrane. Alternative splicing of exons $4,4 b$ and $5 b$ result in eight different mRNA isoforms, and both their functional relevance and subcellular localisation are currently being investigated. ${ }^{156}$ Over 140 pathogenic mutations have been identified and these cluster in two specific regions: the GTPase region (exons 8-15) and the C-terminus which is the proposed site of the GTPase effector domain. The majority of OPA1 mutations ( $~ 50 \%$ ) lead to premature termination codons (PTCs) as a result of nonsense mutations or frameshifts from small insertions, deletions or splice site mutations (eOPA1 database at http://lbbma.univ-angers.fr/lbbma.php?id =9) ${ }^{157}$ These truncated mRNAs are unstable and get degraded by specific pathways (nonsense mediated mRNA decay), which are in-built protective cellular mechanisms against mutant proteins with possible dominant negative effects. ${ }^{158-160}$ The reduced Opa1 protein expression levels observed in these cases support the role of haploinsufficiency in DOA and this is further substantiated by one family with a microdeletion resulting in complete loss of one copy of the OPA1 gene. ${ }^{161}$ However, $~ 30 \%$ of OPA1 mutations are missense mutations within or close to the GTPase domain and these could exert their pathogenic effect via a deleterious, gain of function mechanism. ${ }^{162-164}$

\section{Gene expression}

The spatial localisation and expression pattern of the Opa1 protein have been examined in a wide range of post-mitotic human and murine tissues. The Opa1 protein is highly expressed in the RGC layer but it is also found at comparable levels in the photoreceptor, inner and outer plexiform retinal layers. ${ }^{165} 166$ In the human optic nerve, Opa1 was detected along the axonal tracts both in the pre- and post-lamina cribosa regions. ${ }^{167} 168$ The Opa1 protein is ubiquitous and abundant levels have been identified in non-ocular tissues such as the inner ear and various areas of the human brain, with a similar distribution pattern of the different isoforms. ${ }^{169}{ }^{170}$ Overall, these immunohistochemical studies indicate that differential tissue expression of the OPA1 gene or its isoforms do not seem to underlie the selective vulnerability of RGCs in DOA.

\section{Protein function}

The Opa1 protein is part of the large, dynamin GTPase family of mechanoenzymes and it was first identified in a screen for nuclear genes required for mtDNA maintenance in the budding yeast Saccharomyces cerevisiae. Both the human and yeast (Mgm1+) homologues show a high degree of evolutionary conservation and functional studies in DOA have revealed several other important cellular roles in addition to mtDNA maintenance. ${ }^{171} 172$

\section{Mitochondrial maintenance}

Opa1 is an important pro-fusion protein and works in tandem with other members of the dynamin related mitofusin family (mfn-1 and mfn-2) to balance the pro-fission effects of other GTPases such as Drp1 and Fis-1. ${ }^{173}{ }^{174}$ It is therefore not surprising that mitochondrial network disruption is a key pathological feature seen in fibroblasts from DOA patients and other tissue cultures, including RGCs, where the expression of the Opa1 protein has been disrupted-for example, by small interfering RNAs. ${ }^{162} 170175176$ Instead of a typical elongated, filamentous mitochondrial network, the latter becomes highly fragmented, with isolated mitochondria showing aberrant balloon-like enlargements. Transmission electron microscopy (TEM) also confirms altered mitochondrial ultrastructure with abnormal mitochondrial cristae organisation and paracrystalline inclusion bodies. ${ }^{162}$

Fusion is postulated to subserve a protective biological function by allowing the exchange and complementation of mitochondrial contents. ${ }^{177}{ }^{178}$ In this respect, neuronal cells with deficient mitochondrial fusion show a loss of mtDNA nucleoids and this important finding provides a possible disease mechanism, with the reduced expression of essential, mtDNA encoded, respiratory chain subunits resulting in a bioenergetic deficit, increased ROS levels and a greater susceptibility to undergo apoptosis. ${ }^{179} 180$ These deleterious consequences could also contribute to the formation and clonal expansion of secondary mtDNA abnormalities such as mtDNA deletions, which have recently been identified in a subgroup of DOA families with a more complex multi-system involvement in addition to the optic neuropathy. ${ }^{162-164}$

\section{Oxidative phosphorylation}

Impaired mitochondrial biogenesis is central to the pathophysiology in DOA and there is good experimental evidence to support a predominant complex I defect. There is reduced mitochondrial membrane potential and ATP synthesis in fibroblast cultures carrying pathogenic OPA1 mutations, ${ }^{181} 182$ and in vivo disturbance of oxidative metabolism was evident in the calf muscle of patients with DOA using ${ }^{31} \mathrm{P}-\mathrm{MRS} .{ }^{183}$ Immunoprecipitation studies also suggest that the Opa1 protein, in conjunction with other structural proteins such as the apoptosis inducing factor (AIF), interacts directly with complexes I, II and III and plays an important role in the assembly and stabilisation of their various component subunits. ${ }^{176}$ This provides another causal link between OPA1 mutations and the resulting mitochondrial respiratory chain defect in DOA. 


\section{Apoptosis}

Apoptosis is the final common pathway leading to RGC loss in DOA and cell death is likely be complex, being triggered by a combination of several interacting factors. Opa1 is processed by various, inner membrane proteases which include the presenilin associated rhomboid-like protein (Parl) and paraplegin, and this proteolytic cleavage results in a soluble, intermembrane form in addition to the integral, membrane bound form. ${ }^{184-186}$ These two proteins combine into oligomers which modulate the morphology of the inner mitochondrial membrane and the tightness of the cristae junctions, a process independent of the role of Opa1 in controlling fusion. ${ }^{187}$ Downregulation of Opa1 leads to aberrant cristae remodelling and the release of cytochrome $c$ which is normally sequestered in the narrow junctions within the cristae. ${ }^{175} 188$ This will either be sufficient on its own to induce the apoptotic cascade or will sensitise the cell to other pro-apoptotic stimuli such as AIF, increased ROS or the dissipation of the mitochondrial membrane potential.

\section{Animal models}

There are now two established mouse models of DOA, with heterozygous mutations in exon 8 (c.1051C $>\mathrm{T}$ ) and intron 10 (c. $1065+5 \mathrm{~g}>\mathrm{a}$ ) of the OPA1 gene. ${ }^{189} 190$ These two mutations are truncative, resulting in a $50 \%$ reduction in the expression of the Opa1 protein, and therefore represent a haploinsufficiency disease mechanism. In both models, homozygous mutant mice (OPA1-/-) died in utero during embryogenesis, highlighting the central role played by the Opa1 protein in early development. Heterozygous OPA1+/- mice faithfully replicated the human phenotype exhibiting a slowly progressive optic neuropathy and demonstrating objective reduction in visual function on psychophysical testing. There was a gradual loss of RGCs, leading to thinning of the retinal nerve fibre layer, and the surviving optic nerve axons had an abnormal morphology with swelling, distorted shapes, irregular areas of demyelination and myelin aggregates. Mitochondria within these axons showed disorganised cristae structures on TEM and cultured fibroblasts showed fragmentation of the mitochondrial network. These two OPA1 mouse models represent powerful tools for dissecting the pathways mediating the preferential loss of RGCs in DOA, by allowing functional studies to be performed directly on these specialised cells, something which is not possible in humans given the lack of ocular tissues. These mutant mice will also prove useful when investigating the potential therapeutic benefit of future biological agents which could be injected into the vitreous cavity, allowing direct access with the RGC layer.

\section{Expanding phenotype}

The hallmark of DOA is bilateral visual failure, but sensorineural deafness is a well reported association which is more commonly observed with some pathogenic mutations such as the p.R $445 \mathrm{H}$ mutation. ${ }^{191-193}$ In his original description, Kjer also documented neurodevelopmental abnormalities in $10 \%$ of his
Dutch cohort, although this has not been reported in other populations. ${ }^{120} 125$ More recently, DOA families have been described where the optic atrophy was segregating with additional ocular and extraocular features such as progressive external ophthalmoplegia, ptosis, myopathy, ataxia, neuropathy, and an MS-like disorder. ${ }^{162-164} 194$ These syndromal variants of DOA, so-called "DOA plus", have been linked with the accumulation of multiple mtDNA deletions, a finding consistent with the presence of cytochrome $c$ oxidase (COX) deficient fibres in limb muscle biopsies from affected individuals. ${ }^{195}$ All of the causative OPA1 mutations in these families were missense mutations with most, but not all of them, within the catalytic GTPase site of the protein. Although the actual proportion of families with these "DOA plus" phenotypes is as yet unknown, clinicians need to be aware of these additional clinical features as these can be subtle and therefore easily missed if not looked for specifically.

\section{Genetic counselling}

There is currently no treatment to influence the disease process in DOA and clinical management, as for LHON, is supportive. Despite DOA being an autosomal dominant Mendelian disorder, genetic counselling for mutational carriers is difficult because of the pronounced inter- and intra-familial variability in the visual phenotype. There are no definite genotype-phenotype correlations but missense mutations within the GTPase protein domain are more likely to result in a complex, multisystemic involvement, although it must be stressed that this observation requires further investigation in a larger cohort of DOA families.

With the availability of molecular testing for OPA1 becoming more accessible, an increasing number of individuals with pathogenic mutations are being identified who are otherwise visually unaffected. The penetrance is $>80 \%$ in well characterised, multi-generational families but figures as low as $43 \%$ have been reported, probably reflecting the different assessment criteria used (range 43-100\%). ${ }^{132} 196197$ This incomplete penetrance together with the variable clinical expressivity in both pure DOA and "DOA plus" families clearly imply that other, as yet unidentified, secondary factors are potentiating the deleterious effects of the OPA1 mutations.

\section{MITOCHONDRIAL OPTIC NEUROPATHIES}

The concept of inherited mitochondrial optic neuropathies is expanding with evidence of impaired mitochondrial function in other genetic diseases where optic nerve dysfunction is a recognised clinical feature (table 5). These include: (1) Friedreich's ataxia where up to a third of cases have an optic neuropathy ${ }^{198}{ }^{199}$; (2) hereditary motor and sensory neuropathy type 6 (HMSN-6), a variant of Charcot-Marie-Tooth (CMT) disease defined by the presence of both optic atrophy and peripheral neuropathy ${ }^{200201}$; and (3) the hereditary spastic paraplegias (HSP). ${ }^{202-204}$

Table 5 Other inherited optic neuropathies linked to mitochondrial dysfunction

\begin{tabular}{|c|c|c|c|c|c|}
\hline Disease & OMIM & Inheritance & Gene (protein) & Protein function & References \\
\hline Friedreich's ataxia & 229300 & $\mathrm{Ar}$ & FXN (frataxin) & $\begin{array}{l}\text { Component of iron-sulfur clusters: regulation of mitochondrial respiratory chain } \\
\text { activity and anti-oxidant properties }\end{array}$ & 253,254 \\
\hline HMSN-6 & 601152 & $\mathrm{Ad}$ & MFN2 (mitofusin-2) & $\begin{array}{l}\text { Mitochondrial outer membrane GTPase: pro-fusion protein involved in } \\
\text { maintenance of the mitochondrial network and mtDNA nucleoids (cf Opa1) }\end{array}$ & $216,217,255$ \\
\hline HSP-7 & 607259 & $\mathrm{Ar}$ & SPG7 (paraplegin) & $\begin{array}{l}\text { Mitochondrial inner membrane protease: cleavage of Opa-1, control of } \\
\text { mitochondrial ribosomal assembly and degradation of misfolded proteins }\end{array}$ & 219,256 \\
\hline
\end{tabular}


Glaucoma is the second most common cause of blindness in developed countries and accounts for about $10 \%$ of all blind registration in the UK. ${ }^{205}$ It is a primary, acquired optic neuropathy with a strong genetic component and OPA1 mutations have been identified in a number of patients initially diagnosed with normal tension glaucoma, highlighting the similarities in optic disc features shared with DOA. ${ }^{206}{ }^{207}$ It is of note therefore that some studies have shown an association between the risk of developing glaucoma and certain OPA1 polymorphic variants, ${ }^{208-210}$ with other investigators reporting mtDNA abnormalities in their glaucoma cohorts, such as an increased mtDNA copy number and reduced respiratory chain activities in peripheral blood lymphocytes. ${ }^{211}$ Although further studies are needed, these findings suggest a possible mitochondrial influence on the pathogenesis of glaucoma.

\section{UNIFYING HYPOTHESIS}

The common theme in the various optic neuropathies described in this review is the vulnerability of RGCs to mitochondrial dysfunction. Although there is a high level of mitochondrial enzyme activity in $\mathrm{RGCs},{ }^{212}$ this phenomenon cannot be explained by a simple energetic deficit since photoreceptors have a much higher oxidative demand than RGCs and other mitochondrial disorders characterised by more severe complex I defects do not universally cause optic atrophy. It is possible that RGCs are preferentially involved because they are more sensitive to subtle imbalances in cellular redox state or increased ROS levels, but an attractive hypothesis implicates the differential mitochondrial concentration observed at the lamina cribosa. ${ }^{213}$ The lamina cribosa is a perforated collagen plate that marks the anatomical transition from the unmyelinated (prelaminar) to the myelinated (post-laminar) segment of the human optic nerve. The pre-laminar section has a much higher concentration of mitochondria to support the higher energy demands of unmyelinated nerve conduction and it is likely that active processes involving the cytoskeletal architecture are needed to maintain this sharp mitochondrial gradient. ${ }^{214} 215$ Pathological mechanisms which disrupt this unique structural feature would lead to impaired axonal transport, as seen in CMT $^{179} 216217$ and HSP, ${ }^{218219}$ and set up a vicious circle with fragmentation of the mitochondrial network at the lamina cribosa exacerbating even subtle mitochondrial energy deficits and eventually precipitating apoptotic cell death.

\section{CONCLUSION}

LHON and DOA show an intriguing degree of clinical and mechanistic overlap, with both disorders caused by the selective degeneration of the RGC layer. They are the two most common inherited optic neuropathies and they provide strong evidence that the maintenance of RGCs is heavily dependent upon normal mitochondrial function. This is further substantiated by recent studies pointing towards a mitochondrial link in sporadic glaucoma and other genetic disorders where optic nerve dysfunction is a prominent clinical feature. Although major advances have been achieved in the two decades since the primary LHON mutations were identified, several key questions remain unanswered. What secondary factors account for the notable incomplete penetrance and male bias in LHON? What explains the variable disease expression in DOA, and why is there no gender bias in this disorder, given the similarity to LHON? What are the causative nuclear genes in OPA1-negative families and will they also involve mitochondrial dysfunction? What mechanisms underpin the preferential loss of RGCs in these mitochondrial optic neuropathies? The characterisation of recently developed animal models and future genetic and functional studies will hopefully reveal important pathophysiological pathways amenable to therapeutic interventions.

Acknowledgements: PFC is a Wellcome Trust Senior Fellow in Clinical Science and PYWM is an MRC Clinical Research Fellow.

Competing interests: None.

\section{REFERENCES}

1. Schaefer AM, McFarland R, Blakely EL, He L, Whittaker RG, Taylor RW, Chinnery PF, Turnbull DM. Prevalence of mitochondrial DNA disease in adults. Ann Neurol 2008;63:35-9.

2. Elliott HR, Samuels DC, Eden JA, Relton CL, Chinnery PF. Pathogenic mitochondrial DNA mutations are common in the general population. Am J Hum Genet 2008;83:254-60.

3. Leber $\mathbf{T}$. Ueber hereditaere und congenital angelegte sehnervenleiden. Graefes Arch Opthal 1871:17:249-91.

4. Bell J. Hereditary optic atrophy (Leber's disease). In: Pearson K, ed. The treasury of human inheritance. Cambridge: Cambridge University Press, 1931:345-423.

5. Imai Y, Moriwaki D. A probable case of cytoplasmic inheritance in man: a critique of Leber's disease. J Genet 1936;33:163-7.

6. Lundsgaard R. A genealogic, genetic and clinical study of 101 cases of retrobulbar optic neuritis in 20 Danish families. Acta Ophthalmol 1944;21:1-306.

7. Wallace DC, Singh G, Lott MT, Hodge JA, Schurr TG, Lezza AM, Elsas LJd, Nikoskelainen EK. Mitochondrial DNA mutation associated with Leber's hereditary optic neuropathy. Science 1988;242:1427-30.

8. Mackey DA, Oostra RJ, Rosenberg T, Nikoskelainen E, Bronte-Stewart J, Poulton J, Harding AE, Govan G, Bolhuis PA, Norby S. Primary pathogenic mtDNA mutations in multigeneration pedigrees with Leber hereditary optic neuropathy. Am J Hum Genet 1996:59:481-5.

9. Mashima Y, Yamada K, Wakakura M, Kigasawa K, Kudoh J, Shimizu N, Oguchi Y Spectrum of pathogenic mitochondrial DNA mutations and clinical features in Japanese families with Leber's hereditary optic neuropathy. Curr Eye Res 1998;17:403-8.

10. Yen MY, Wang AG, Chang WL, Hsu WM, Liu JH, Wei YH. Leber's hereditary optic neuropathy-the spectrum of mitochondrial DNA mutations in Chinese patients. Jpn J Ophthalmol 2002;46:45-51.

11. Macmillan C, Kirkham T, Fu K, Allison V, Andermann E, Chitayat D, Fortier D, Gans M, Hare H, Quercia N, Zackon D, Shoubridge EA. Pedigree analysis of French Canadian families with T14484C Leber's hereditary optic neuropathy. Neurology 1998:50:417-22.

12. Macmillan C, Johns TA, Fu K, Shoubridge EA. Predominance of the T14484C mutation in French-Canadian families with Leber hereditary optic neuropathy is due to a founder effect [letter]. Am J Hum Genet 2000;66:332-5.

13. Taylor RW, Jobling MS, Turnbull DM, Chinnery PF. Frequency of rare mitochondrial DNA mutations in patients with suspected Leber's hereditary optic neuropathy. J Med Genet 2003;40:e85.

14. Man PY, Griffiths PG, Brown DT, Howell N, Turnbull DM, Chinnery PF. The epidemiology of Leber hereditary optic neuropathy in the North East of England. Am J Hum Genet 2003;72:333-9.

15. Spruijt L, Kolbach DN, de Coo RF, Plomp AS, Bauer NJ, Smeets HJ, de DieSmulders CEM. Influence of mutation type on clinical expression of Leber hereditary optic neuropathy. Am J Ophthalmol 2006;141:676-82.

16. Puomila A, Hamalainen P, Kivioja S, Savontaus ML, Koivumaki S, Huoponen K, Nikoskelainen E. Epidemiology and penetrance of Leber hereditary optic neuropathy in Finland. Eur J Hum Genet 2007;15:1079-89.

17. Mackey DA, Buttery RG. Leber hereditary optic neuropathy in Australia. Aust N Z J Ophthalmol 1992;20:177-84.

18. Yu-Wai-Man $\mathbf{P}$, Bateman DE, Hudson G, Griffiths PG, Chinnery PF. Leber hereditary optic neuropathy presenting in a 75-year-old man. J Neuroophthalmol 2008;28:155.

19. Dagi LR, Rizzo JF, 3rd, Cestari DM. Leber hereditary optic neuropathy in an octogenarian. J Neuroophthalmol 2008;28:156.

20. Harding AE, Sweeney MG, Govan GG, Riordan-Eva P. Pedigree analysis in Leber hereditary optic neuropathy families with a pathogenic mtDNA mutation. Am J Hum Genet 1995:57:77-86.

21. Newman NJ, Lott MT, Wallace DC. The clinical characteristics of pedigrees of Leber's hereditary optic neuropathy with the 11778 mutation. Am J Ophthalmol 1991;111:750-62.

22. Johns DR, Smith KH, Miller NR. Leber's hereditary optic neuropathy. Clinical manifestations of the 3460 mutation. Arch Ophthalmol 1992;110:1577-81.

23. Johns DR, Heher KL, Miller NR, Smith KH. Leber's hereditary optic neuropathy. Clinical manifestations of the 14484 mutation. Arch Ophthalmol 1993;111:495-8.

24. Biousse V, Brown MD, Newman NJ, Allen JC, Rosenfeld J, Meola G, Wallace DC De novo 14484 mitochondrial DNA mutation in monozygotic twins discordant for Leber's hereditary optic neuropathy. Neurology 1997;49:1136-8.

25. Savini G, Barboni P, Valentino ML, Montagna P, Cortelli P, De Negri AM, Sadun F, Bianchi S, Longanesi L, Zanini M, Carelli V. Retinal nerve fiber layer evaluation by optical coherence tomography in unaffected carriers with Leber's hereditary optic neuropathy mutations. Ophthalmology 2005;112:127-31. 
26. Quiros PA, Torres RJ, Salomao S, Berezovsky A, Carelli V, Sherman J, Sadun F, De Negri A, Belfort R, Sadun AA. Colour vision defects in asymptomatic carriers of the Leber's hereditary optic neuropathy (LHON) mtDNA 11778 mutation from a large Brazilian LHON pedigree: a case-control study. Br J Ophthalmol 2006:90:150-3.

27. Sadun AA, Salomao SR, Berezovsky A, Sadun F, Denegri AM, Quiros PA, Chicani F, Ventura D, Barboni P, Sherman J, Sutter E, Belfort R Jr, Carelli V, Patsi J, Kervinen M, Finel M, Hassinen IE. Subclinical carriers and conversions in Leber hereditary optic neuropathy: a prospective psychophysical study. Trans Am Ophthalmol Soc 2006;104:51-61.

28. Nikoskelainen EK, Huoponen K, Juvonen V, Lamminen T, Nummelin K, Savontaus ML. Ophthalmologic findings in Leber hereditary optic neuropathy, with special reference to mtDNA mutations. Ophthalmology 1996;103:504-14.

29. Sugisaka E, Ohde H, Shinoda K, Mashima Y. Woman with atypical unilateral Leber's hereditary optic neuropathy with visual improvement. Clin Exp Ophthalmol 2007:35:868-70.

30. Nikoskelainen EK. Clinical picture of LHON. Clin Neurosci 1994;2:115-20.

31. Riordan-Eva $\mathbf{P}$, Harding AE. Leber's hereditary optic neuropathy: the clinical relevance of different mitochondrial DNA mutations. J Med Genet 1995;32:81-7.

32. Mackey D, Howell N. A variant of Leber hereditary optic neuropathy characterized by recovery of vision and by an unusual mitochondrial genetic etiology. Am J Hum Genet 1992;51:1218-28.

33. Stone EM, Newman NJ, Miller NR, Johns DR, Lott MT, Wallace DC. Visual recovery in patients with Leber's hereditary optic neuropathy and the 11778 mutation. J Clin Neuroophthalmol 1992;12:10-4.

34. Barboni P, Savini G, Valentino ML, La Morgia C, Bellusci C, De Negri AM, Sadun F, Carta A, Carbonelli M, Sadun AA, Carelli V. Leber's hereditary optic neuropathy with childhood onset. Invest Ophthalmol Vis Sci 2006;47:5303-9.

35. Bower SP, Hawley I, Mackey DA. Cardiac arrhythmia and Leber's hereditary optic neuropathy [letter]. Lancet 1992;339:1427-8.

36. Nikoskelainen EK, Savontaus ML, Huoponen K, Antila K, Hartiala J. Pre-excitation syndrome in Leber's hereditary optic neuropathy. Lancet 1994;344:857-8.

37. Nikoskelainen EK, Marttila RJ, Huoponen K, Juvonen V, Lamminen T, Sonninen P, Savontaus ML. Leber's "plus": neurological abnormalities in patients with Leber's hereditary optic neuropathy. J Neurol Neurosurg Psychiatry 1995;59:160-4.

38. Meire FM, Van Coster R, Cochaux P, Obermaier-Kusser B, Candaele C, Martin JJ. Neurological disorders in members of families with Leber's hereditary optic neuropathy (LHON) caused by different mitochondrial mutations. Ophthalm Genet 1995;16:119-26.

39. Mashima Y, Kigasawa K, Hasegawa H, Tani M, Oguchi Y. High incidence of preexcitation syndrome in Japanese families with Leber's hereditary optic neuropathy. Clin Genet 1996;50:535-7

40. De Vries DD, Went LN, Bruyn GW, Scholte HR, Hofstra RM, Bolhuis PA, van Oost BA. Genetic and biochemical impairment of mitochondrial complex I activity in a family with Leber hereditary optic neuropathy and hereditary spastic dystonia. Am J Hum Genet 1996;58:703-11.

41. Howell N, Kubacka I, Xu M, McCullough DA. Leber hereditary optic neuropathy: involvement of the mitochondrial ND1 gene and evidence for an intragenic suppressor mutation. Am J Hum Genet 1991;48:935-42.

42. Jun AS, Brown MD, Wallace DC. A mitochondrial DNA mutation at nucleotide pair 14459 of the NADH dehydrogenase subunit 6 gene associated with maternally inherited Leber hereditary optic neuropathy and dystonia. Proc Natl Acad Sci USA 1994;91:6206-10.

43. Gropman A, Chen TJ, Perng CL, Krasnewich D, Chernoff E, Tifft C, Wong LJ. Variable clinical manifestation of homoplasmic G14459A mitochondrial DNA mutation. Am J Med Genet Part A 2004;124:377-82

44. Tarnopolsky MA, Baker SK, Myint T, Maxner CE, Robitaille J, Robinson BH. Clinical variability in maternally inherited Leber hereditary optic neuropathy with the G14459A mutation. Am J Med Genet Part A 2004:124:372-6.

45. Blakely EL, de Silva R, King A, Schwarzer V, Harrower T, Dawidek G, Turnbull DM, Taylor RW. LHON/MELAS overlap syndrome associated with a mitochondrial MTND1 gene mutation. Eur J Hum Genet2005:13:623-7.

46. Spruijt L, Smeets HJ, Hendrickx A, Bettink-Remeijer MW, Maat-Kievit A, Schoonderwoerd KC, Sluiter W, de Coo IF, Hintzen RO. A MELAS-associated ND1 mutation causing Leber hereditary optic neuropathy and spastic dystonia. Arch Neurol 2007;64:890-3

47. Harding AE, Sweeney MG, Miller DH, Mumford CJ, Kellar-Wood H, Menard D, McDonald WI, Compston DA. Occurrence of a multiple sclerosis-like illness in women who have a Leber's hereditary optic neuropathy mitochondrial DNA mutation. Brain 1992:115:979-89.

48. Kellar-Wood H, Robertson N, Govan GG, Compston DA, Harding AE. Leber's hereditary optic neuropathy mitochondrial DNA mutations in multiple sclerosis. Ann Neurol 1994;36:109-12.

49. Jansen PH, van der Knaap MS, de Coo IF. Leber's hereditary optic neuropathy with the 11778 mtDNA mutation and white matter disease resembling multiple sclerosis: clinical, MRI and MRS findings. J Neurol Sci 1996;135:176-80.

50. Vanopdenbosch L, Dubois B, D'Hooghe MB, Meire F, Carton H. Mitochondrial mutations of Leber's hereditary optic neuropathy: a risk factor for multiple sclerosis. J Neurol 2000;247:535-43.

51. Govan GG, Smith PR, Kellar-Wood H, Schapira AH, Harding AE. HLA class ॥ genotypes in Leber's hereditary optic neuropathy. J Neurol Sci 1994;126:193-6.

52. Smith PR, Cooper JM, Govan GG, Riordan-Eva P, Harding AE, Schapira AH. Antibodies to human optic nerve in Leber's hereditary optic neuropathy. J Neurol Sci 1995;130:134-8.
53. Chalmers RM, Govan GG, Schapira AH, Harding AE. HLA class I genotypes in Leber's hereditary optic neuropathy. J Neurol Sci 1996;135:173-5.

54. Sapey E, Burdon MA, Nightingale S. Evidence of active demyelination in a man with Leber's hereditary optic neuropathy mtDNA 14484 genotype. Neuro-Ophthalmology 2001;26:119-26.

55. Kovacs GG, Hoftberger R, Majtenyi K, Horvath R, Barsi P, Komoly S, Lassmann H Budka H, Jakab G. Neuropathology of white matter disease in Leber's hereditary optic neuropathy. Brain 2005;128:35-41.

56. Sherman J, Kleiner L. Visual-system dysfunction in Lebers hereditary optic neuropathy. Clin Neurosci 1994;2:121-9.

57. Smith JL, Tse DT, Byrne SF, Johns DR, Stone EM. Optic nerve sheath distention in Leber's optic neuropathy and the significance of the "Wallace mutation". J Clin Neuroophthalmol 1990;10:231-8.

58. de Gottrau P, Buchi ER, Daicker B. Distended optic nerve sheaths in Leber's hereditary optic neuropathy. J Clin Neuroophthalmol 1992;12:89-93.

59. Dotti MT, Caputo N, Signorini E, Federico A. Magnetic resonance imaging findings in Leber's hereditary optic neuropathy. Eur Neurol 1992:32:17-9.

60. Mashima Y, Oshitari K, Imamura Y, Momoshima S, Shiga H, Oguchi Y. Orbital high resolution magnetic resonance imaging with fast spin echo in the acute stage of Leber's hereditary optic neuropathy. J Neurol Neurosurg Psychiatry 1998;64:124-7.

61. Vaphiades MS, Newman NJ. Optic nerve enhancement on orbital magnetic resonance imaging in Leber's hereditary optic neuropathy. J Neuroophthalmol 1999;19:238-9.

62. Inglese $\mathbf{M}$, Rovaris M, Bianchi S, Mancardi GL, Ghezzi A, Salvi F, Cortelli P, Filippi M. MRI, MTI, and DWI study of the optic nerve, brain, and cervical cord from patients with Leber hereditary optic neuropathy. Neurology 2000;54:A320-A.

63. Barbiroli B, Montagna P, Cortelli P, lotti S, Lodi R, Barboni P, Monari L, Lugaresi E, Frassineti C, Zaniol P. Defective brain and muscle energy metabolism shown by in vivo 31P magnetic resonance spectroscopy in nonaffected carriers of $11778 \mathrm{mtDNA}$ mutation. Neurology 1995;45:1364-9.

64. Cortelli P, Montagna P, Pierangeli G, Lodi R, Barboni P, Liguori R, Carelli V, lotti S, Zaniol P, Lugaresi E, Barbiroli B. Clinical and brain bioenergetics improvement with idebenone in a patient with Leber's hereditary optic neuropathy: a clinical and 31PMRS study. J Neurol Sci 1997;148:25-31.

65. Lodi R, Taylor DJ, Tabrizi SJ, Kumar S, Sweeney M, Wood NW, Styles P, Radda GK, Schapira AHV. In vivo skeletal muscle mitochondrial function in Leber's hereditary optic neuropathy assessed by P-31 magnetic resonance spectroscopy. Ann Neurol 1997:42:573-9.

66. Lodi R, Montagna P, Cortelli P, lotti S, Cevoli S, Carelli V, Barbiroli B. 'Secondary' 4216/ND1 and 13708/ND5 Leber's hereditary optic neuropathy mitochondrial DNA mutations do not further impair in vivo mitochondrial oxidative metabolism when associated with the 11778/ND4 mitochondrial DNA mutation. Brain 2000;123:1896-902.

67. Lodi R, Carelli V, Cortelli P, lotti S, Valentino ML, Barboni P, Pallotti F, Montagna P, Barbiroli B. Phosphorus MR spectroscopy shows a tissue specific in vivo distribution of biochemical expression of the G3460A mutation in Leber's hereditary optic neuropathy. J Neuro Neurosurg Psychiatry 2002;72:805-7.

68. Beretta S, Mattavelli L, Sala G, Tremolizzo L, Schapira AH, Martinuzzi A, Carelli V Ferrarese C. Leber hereditary optic neuropathy mtDNA mutations disrupt glutamate transport in cybrid cell lines. Brain 2004;127:2183-92.

69. Beretta S, Wood JPM, Derham B, Sala G, Tremolizzo L, Ferrarese C, Osborne NN Partial mitochondrial complex I inhibition induces oxidative damage and perturbs glutamate transport in primary retinal cultures. Relevance to Leber hereditary optic neuropathy (LHON). Neurobiol Dis 2006;24:308-17.

70. Floreani M, Napoli E, Martinuzzi A, Pantano G, De Riva V, Trevisan R, Bisetto E, Valente L, Carelli V, Dabbeni-Sala F. Antioxidant defences in cybrids harboring mtDNA mutations associated with Leber's hereditary optic neuropathy. Febs $J$ 2005:272:1124-35.

71. Carelli V, Rugolo M, Sgarbi G, Ghelli A, Zanna C, Baracca A, Lenaz G, Napoli E, Martinuzzi A, Solaini G. Bioenergetics shapes cellular death pathways in Leber's hereditary optic neuropathy: a model of mitochondrial neurodegeneration. Biochim Biophys Acta Bioenerg 2004;1658:172-9

72. Danielson SR, Wong A, Carelli V, Martinuzzi A, Schapira AH, Cortopassi GA. Cells bearing mutations causing Leber's hereditary optic neuropathy are sensitized to Fasinduced apoptosis. J Biol Chem 2002;277:5810-5

73. Zanna C, Ghelli A, Porcelli AM, Martinuzzi A, Carelli V, Rugolo M. Caspase-independent death of Leber's hereditary optic neuropathy cybrids is driven by energetic failure and mediated by AIF and endonuclease G. Apoptosis 2005;10:997-1007

74. Klivenyi P, Karg E, Rozsa C, Horvath R, Komoly S, Nemeth I, Turi S, Vecsei L. alphaTocopherol/lipid ratio in blood is decreased in patients with Leber's hereditary optic neuropathy and asymptomatic carriers of the $11778 \mathrm{mtDNA}$ mutation. J Neurol Neurosurg Psychiatry 2001;70:359-62.

75. Yen MY, Kao SH, Wang AG, Wei YH. Increased 8-hydroxy-2'-deoxyguanosine in leukocyte DNA in Leber's hereditary optic neuropathy. Invest Ophthalmol Vis Sci 2004;45:1688-91.

76. Zhang $\mathbf{X}$, Jones $\mathbf{D}$, Gonzalez-Lima F. Mouse model of optic neuropathy caused by mitochondrial complex I dysfunction. Neurosci Lett 2002;326:97-100.

77. Qi XP, Lewin AS, Hauswirth WW, Guy J. Suppression of complex I gene expression induces optic neuropathy. Ann Neurol 2003:53:198-205.

78. Qi XP, Sun L, Lewin AS, Hauswirth WW, Guy J. The mutant human ND4 subunit of complex I induces optic neuropathy in the mouse. Invest Ophthalmol Vis Sci 2007:48:1-10. 
79. Smith KH, Johns DR, Heher KL, Miller NR. Heteroplasmy in Leber's hereditary optic neuropathy. Arch Ophthalmol 1993;111:1486-90.

80. Chinnery PF, Andrews RM, Turnbull DM, Howell NN. Leber hereditary optic neuropathy: does heteroplasmy influence the inheritance and expression of the G11778A mitochondrial DNA mutation? Am J Med Genet 2001;98:235-43.

81. Brown WM, George M Jr, Wilson AC. Rapid evolution of animal mitochondrial DNA. Proc Natl Acad Sci USA 1979;76:1967-71

82. Wallace DC, Brown MD, Lott MT. Mitochondrial DNA variation in human evolution and disease. Gene 1999;238:211-30.

83. Torroni A, Huoponen K, Francalacci P, Petrozzi M, Morelli L, Scozzari R, Obinu D, Savontaus ML, Wallace DC. Classification of European mtDNAs from an analysis of three European populations. Genetics 1996;144:1835-50.

84. Hofmann S, Jaksch M, Bezold R, Mertens S, Aholt S, Paprotta A, Gerbitz KD. Population genetics and disease susceptibility: characterization of central European haplogroups by mtDNA gene mutations, correlation with D loop variants and association with disease. Hum Mol Genet 1997;6:1835-46.

85. Hudson G, Carelli V, Spruijt L, Gerards M, Mowbray C, Achilli A, Pyle A, Elson J Howell N, La Morgia C, Valentino ML, Huoponen K, Savontaus ML, Nikoskelainen E, Sadun AA, Salomao SR, Belfort R, Griffiths P, Man PYW, de Coo RFM, Horvath R, Zeviani M, Smeets HJT, Torroni A, Chinnery PF. Clinical expression of Leber hereditary optic neuropathy is affected by the mitochondrial DNA-haplogroup background. Am J Hum Genet 2007:81:228-33.

86. Dudkina NV, Eubel H, Keegstra W, Boekema EJ, Braun HP. Structure of a mitochondrial supercomplex formed by respiratory-chain complexes I and III. Proc Natl Acad Sci USA 2005:102:3225-9.

87. Carelli V, Achilli A, Valentino ML, Rengo C, Semino O, Pala M, Olivieri A, Mattiazzi M, Pallotti F, Carrara F, Zeviani M, Leuzzi V, Carducci C, Valle G, Simionati B, Mendieta L, Salomao S, Belfort R Jr, Sadun AA, Torroni A. Haplogroup effects and recombination of mitochondrial DNA: novel clues from the analysis of Leber hereditary optic neuropathy pedigrees. Am J Hum Genet 2006;78:564-74.

88. Vergani L, Martinuzzi A, Carelli V, Cortelli P, Montagna P, Schievano G, Carrozzo R, Angelini $\mathrm{C}$, Lugaresi E. MtDNA mutations associated with Leber's hereditary optic neuropathy: studies on cytoplasmic hybrid (cybrid) cells. Biochem Biophys Res Commun 1995;210:880-8

89. Tharaphan P, Chuenkongkaew WL, Luangtrakool K, Sanpachudayan T, Suktitipat B, Suphavilai R, Srisawat C, Sura T, Lertrit P. Mitochondrial DNA haplogroup distribution in pedigrees of Southeast Asian G11778A Leber hereditary optic neuropathy. J Neuroophthalmol 2006:26:264-7.

90. Bu XD, Rotter Jl. X chromosome-linked and mitochondrial gene control of Leber hereditary optic neuropathy: evidence from segregation analysis for dependence on X chromosome inactivation. Proc Natl Acad Sci USA 1991:88:8198-202.

91. Bu X, Rotter Jl. Leber hereditary optic neuropathy: estimation of number of embryonic precursor cells and disease threshold in heterozygous affected females at the X-linked locus. Clin Genet 1992;42:143-8.

92. Nakamura M, Fujiwara $Y$, Yamamoto M. The two locus control of Leber hereditary optic neuropathy and a high penetrance in Japanese pedigrees. Hum Genet 1993;91:339-41.

93. Pegoraro E, Carelli V, Zeviani M, Cortelli P, Montagna P, Barboni P, Angelini C, Hoffman EP. X-inactivation patterns in female Leber's hereditary optic neuropathy patients do not support a strong X-linked determinant. Am J Med Genet 1996:61:356-62.

94. Oostra RJ, Kemp S, Bolhuis PA, Bleeker-Wagemakers EM. No evidence for skewed' inactivation of the X-chromosome as cause of Leber's hereditary optic neuropathy in female carriers. Hum Genet 1996;97:500-5

95. Hudson G, Carelli V, Horvath R, Zeviani M, Smeets HJ, Chinnery PF. X-Inactivation patterns in females harboring mtDNA mutations that cause Leber hereditary optic neuropathy. Mol Vis 2007;13:2339-43.

96. Chen JD, Cox I, Denton MJ. Preliminary exclusion of an X-linked gene in Leber optic atrophy by linkage analysis. Hum Genet 1989;82:203-7.

97. Carvalho MR, Muller B, Rotzer E, Berninger T, Kommerell G, Blankenagel A, Savontaus ML, Meitinger T, Lorenz B. Leber's hereditary optic neuroretinopathy and the X-chromosomal susceptibility factor: no linkage to DXs7. Hum Hered 1992;42(5):316-20.

98. Sweeney MG, Davis MB, Lashwood A, Brockington M, Toscano A, Harding AE. Evidence against an X-linked locus close to DXS7 determining visual loss susceptibility in British and Italian families with Leber hereditary optic neuropathy. Am J Hum Genet 1992;51:741-8.

99. Handoko HY, Wirapati PJ, Sudoyo HA, Sitepu M, Marzuki S. Meiotic breakpoint mapping of a proposed $X$ linked visual loss susceptibility locus in Leber's hereditary optic neuropathy. J Med Genet 1998;35:668-71.

100. Hudson G, Keers S, Man PYW, Griffiths P, Huoponen K, Savontaus ML, Nikoskelainen E, Zeviani M, Carrara F, Horvath R, Karcagi V, Spruijt L, de Coo IFM, Smeets HJM, Chinnery PF. Identification of an X-chromosomal locus and haplotype modulating the phenotype of a mitochondrial DNA disorder. Am J Hum Genet 2005; 77:1086-91.

101. Shankar SP, Fingert JH, Carelli V, Valentino ML, King TM, Daiger SP, Salomao SR, Berezovsky A, Belfort R Jr, Braun TA, Sheffield VC, Sadun AA, Stone EM. Evidence for a novel $x$-linked modifier locus for Leber hereditary optic neuropathy. Ophthalmic Genet 2008:29:17-24.

102. Nikoskelainen EK, Savontaus ML, Wanne OP, Katila MJ, Nummelin KU. Leber's hereditary optic neuroretinopathy, a maternally inherited disease. A genealogic study in four pedigrees. Arch Ophthalmol 1987:105:665-71.
103. Johns DR, Smith KH, Miller NR, Sulewski ME, Bias WB. Identical twins who are discordant for Leber's hereditary optic neuropathy. Arch Ophthalmol 1993;111:1491-4.

104. Lam BL. Identical twins no longer discordant for Leber's hereditary optic neuropathy [letter]. Arch Ophthalmol 1998;116:956-7.

105. Riordan-Eva P, Sanders MD, Govan GG, Sweeney MG, Da Costa J, Harding AE. The clinical features of Leber's hereditary optic neuropathy defined by the presence of a pathogenic mitochondrial DNA mutation. Brain 1995;118:319-37.

106. Charlmers RM, Harding AE. A case-control study of Leber's hereditary optic neuropathy. Brain 1996;119:1481-6.

107. Tsao K, Aitken PA, Johns DR. Smoking as an aetiological factor in a pedigree with Leber's hereditary optic neuropathy. Br J Ophthalmol 1999:83:577-81.

108. Sadun AA, Carelli V, Salomao SR, Berezovsky A, Quiros PA, Sadun F, DeNegri AM, Andrade R, Moraes M, Passos A, Kjaer P, Pereira J, Valentino ML, Schein S, Belfort R. Extensive investigation of a large Brazilian pedigree of 11778/haplogroup J Lebe hereditary optic neuropathy. Am J Ophthalmol 2003;136:231-8

109. Kerrison JB, Miller NR, Hsu F, Beaty TH, Maumenee IH, Smith KH, Savino PJ, Stone EM, Newman NJ. A case-control study of tobacco and alcohol consumption in Leber hereditary optic neuropathy. Am J Ophthalmol 2000;130:803-12.

110. Mackey DA, Fingert JH, Luzhansky JZ, McCluskey PJ, Howell N, Hall AJH, Pierce $A B$, Hoy JF. Leber's hereditary optic neuropathy triggered by antiretroviral therapy for human immunodeficiency virus. Eye 2003:17:312-7.

111. Sanchez RN, Smith AJ, Carelli V, Sadun AA, Keltner JL. Leber hereditary optic neuropathy possibly triggered by exposure to tire fire. J Neuroophthalmol 2006;26:268-72

112. Carelli V, Franceschini F, Venturi S, Barboni P, Savini G, Barbieri G, Pirro E, La Morgia C, Valentino ML, Zanardi F, Violante FS, Mattioli S. Grand rounds: could occupational exposure to $n$-hexane and other solvents precipitate visual failure in Leber hereditary optic neuropathy? Environ Health Perspect 2007;115:113-5.

113. Howell N, Mackey DA. Low-penetrance branches in matrilineal pedigrees with Leber hereditary optic neuropathy. Am J Hum Genet 1998;63:1220-4.

114. Sadun F, De Negri AM, Carelli V, Salomao SR, Berezovsky A, Andrade R, Moraes M, Passos A, Belfort R, Da Rosa AB, Quiros P, Sadun AA. Ophthalmologic findings in a large pedigree of $11778 /$ Haplogroup $\mathrm{J}$ Leber hereditary optic neuropathy. Am J Ophthalmol 2004:137:271-7.

115. Mashima Y, Kigasawa K, Wakakura M, Oguchi Y. Do idebenone and vitamin therapy shorten the time to achieve visual recovery in Leber hereditary optic neuropathy? J Neuroophthalmol 2000:20:166-70.

116. Carelli V, Valentino ML, Liguori R, Meletti S, Vetrugno R, Provini F, Mancardi GL, Bandini F, Baruzzi A, Montagna P. Leber's hereditary optic neuropathy (LHON/ 11778) with myoclonus: report of two cases. J Neurol Neurosurg Psychiatry 2001;71:813-6

117. Barnils N, Mesa E, Munoz S, Ferrer-Artola A, Arruga J. Response to idebenone and multivitamin therapy in Leber's hereditary optic neuropathy. Arch Soc Esp Oftalmol 2007:82:377-80.

118. Newman NJ, Biousse V, David R, Bhatti MT, Hamilton SR, Farris BK, Lesser RL, Newman SA, Turbin RE, Chen K, Keaney RP. Prophylaxis for second eye involvement in Leber hereditary optic neuropathy: an open-labeled, nonrandomized multicenter trial of topical brimonidine purite. Am J Ophthalmol 2005;140:407-15.

119. Batten B. A family suffering from hereditary optic atrophy. Transactions of the Ophthalmological Society UK 1896:16:125.

120. Kjer B. Infantile optic atrophy with dominant transmission. Dan Med Bull 1956:3:135-41.

121. Lyle WM. Genetic risks. A reference for eye care practitioners. Waterloo, Ontario, Canada: University of Waterloo Press, 1990

122. Thiselton DL, Alexander C, Morris A, Brooks S, Rosenberg T, Eiberg H, Kjer B, Kje P, Bhattacharya SS, Votruba M. A frameshift mutation in exon 28 of the OPA1 gene explains the high prevalence of dominant optic atrophy in the Danish population: evidence for a founder effect. Hum Genet 2001:109:498-502.

123. Kline LB, Glaser JS. Dominant optic atrophy - clinical profile. Arch Ophthalmol 1979:97:1680-6.

124. Hoyt CS. Autosomal dominant optic atrophy - a spectrum of disability. Ophthalmology 1980;87:245-51.

125. Kjer P. Infantile optic atrophy with dominant mode of inheritance: a clinical and genetic study of 19 Danish families. Acta Ophthalmol 1959; (Suppl 54):1-146.

126. Eliott D, Traboulsi El, Maumenee IH. Visual prognosis in autosomal dominant optic atrophy (Kjer type). Am J Ophthalmol 1993;115:360-7.

127. Votruba M, Moore AT, Bhattacharya SS. Clinical features, molecular genetics, and pathophysiology of dominant optic atrophy. J Med Genet 1998;35:793-800.

128. Puomila A, Huoponen K, Mantyjarvi M, Hamalainen P, Paananen R, Sankila EM, Savontaus ML, Somer M, Nikoskelainen E. Dominant optic atrophy: correlation between clinical and molecular genetic studies. Acta Ophthalmol Scandinavica 2005;83:337-46

129. Cohn AC, Toomes C, Hewitt AW, Kearns LS, Inglehearn CF, Craig JE, Mackey DA The natural history of OPA1-related autosomal dominant optic atrophy. $\mathrm{Br} J$ Ophthalmol 2008:24:24.

130. Kjer B, Eiberg $H$, Kjer $P$, Rosenberg T. Dominant optic atrophy mapped to chromosome $3 q$ region. II. Clinical and epidemiological aspects. Acta Ophthalmol Scandinavica 1996:74:3-7.

131. Votruba M, Fitzke FW, Holder GE, Carter A, Bhattacharya SS, Moore AT. Clinical features in affected individuals from 21 pedigrees with dominant optic atrophy. Arch Ophthalmol 1998:116:351-8. 
132. Cohn AC, Toomes C, Potter C, Towns KV, Hewitt AW, Inglehearn CF, Craig JE, Mackey DA. Autosomal dominant optic atrophy: penetrance and expressivity in patients with OPA1 mutations. Am J Ophthalmol 2007;143:656-62.

133. Berninger TA, Jaeger W, Krastel $\mathrm{H}$. Electrophysiology and color perimetry in dominant infantile optic atrophy. Br J Ophthalmol 1991;75:49-52.

134. Bremner FD, Tomlin EA, Shallo-Hoffmann J, Votruba M, Smith SE. The pupil in dominant optic atrophy. Invest Ophthalmol Vis Sci 2001;42:675-8.

135. Votruba M, Thiselton D, Bhattacharya SS. Optic disc morphology of patients with OPA1 autosomal dominant optic atrophy. Br J Ophthalmol 2003;87:48-53.

136. Fournier AV, Damji KF, Epstein DL, Pollock SC. Disc excavation in dominant optic atrophy. Ophthalmology 2001;108:1595-602

137. Ito Y, Nakamura M, Yamakoshi T, Lin J, Yatsuya H, Terasaki H. Reduction of inner retinal thickness in patients with autosomal dominant optic atrophy associated with OPA1 mutations. Invest Ophthalmol Vis Sci 2007:48:4079-86.

138. Kim TW, Hwang JM. Stratus OCT in dominant optic atrophy: features differentiating it from glaucoma. J Glaucoma 2007;16:655-8.

139. Johnston PB, Gaster RN, Smith VC, Tripathi RC. Clinicopathologic study of autosomal dominant optic atrophy. Am J Ophthalmol 1979;88:868-75.

140. Kjer $\mathbf{P}$, Jensen OA, Klinken L. Histopathology of eye, optic-nerve and brain in a case of dominant optic atrophy. Acta Ophthalmol 1983:61:300-12.

141. Votruba M, Leary S, Losseff N, Bhattacharya SS, Moore AT, Miller DH, Moseley IF. $\mathrm{MRI}$ of the intraorbital optic nerve in patients with autosomal dominant optic atrophy. Neuroradiology 2000;42:180-3.

142. Delporto G, Vingolo EM, Steindl K, Forte R, lannaccone A, Rispoli E, Pannarale MR. Clinical heterogeneity of dominant optic atrophy - the contribution of visual function investigations to diagnosis. Graefes Arch Clin Exp Ophthalmol 1994;232:717-27.

143. Holder GE, Votruba M, Carter AC, Bhattacharya SS, Fitzke FW, Moore AT. Electrophysiological findings in dominant optic atrophy (DOA) linking to the OPA1 locus on chromosome 3q 28-qter. Doc Ophthalmol 1998;95:217-28.

144. Alexander C, Votruba M, Pesch UEA, Thiselton DL, Mayer S, Moore A, Rodriguez M, Kellner U, Leo-Kottler B, Auburger G, Bhattacharya SS, Wissinger B. OPA1 encoding a dynamin-related GTPase, is mutated in autosomal dominant optic atrophy linked to chromosome 3q28. Nat Genet 2000;26:211-5.

145. Delettre C, Lenaers G, Griffoin JM, Gigarel N, Lorenzo C, Belenguer P, Pelloquin L, Grosgeorge J, Turc-Carel C, Perret E, Astarie-Dequeker C, Lasquellec L, Arnaud B, Ducommun B, Kaplan J, Hamel CP. Nuclear gene OPA1, encoding a mitochondrial dynamin-related protein, is mutated in dominant optic atrophy. Nat Genet 2000:26:207-10.

146. Davies V, Votruba M. Focus on molecules: the OPA1 protein. Exp Eye Res 2006;83:1003-4.

147. Newman NJ, Biousse V. Hereditary optic neuropathies. Eye 2004;18:1144-60.

148. Fuhrmann N, Alavi MV, Wissinger B. Genomic rearrangements in the OPA1 gene are frequent in patients with autosomal dominant optic atrophy (poster 5387). The Association for Research in Vision and Ophthalmology (ARVO) Annual Meeting. Fort Lauderdale, Florida, 2008

149. Costeff H, Gadoth N, Apter N, Prialnic M, Savir H. A familial syndrome of infantile optic atrophy, movement disorder, and spastic paraplegia. Neurology 1989;39:595-7.

150. Anikster Y, Kleta R, Shaag A, Gahl WA, Elpeleg 0. Type III 3-methylglutaconic aciduria (optic atrophy plus syndrome, or Costeff optic atrophy syndrome): identification of the OPA3 gene and its founder mutation in Iraqi Jews. Am J Hum Genet 2001;69:1218-24.

151. Kleta R, Skovby F, Christensen E, Rosenberg T, Gahl WA, Anikster Y. 3methylglutaconic aciduria type III in a non-Iraqi-Jewish kindred: clinical and molecular findings. Mol Genet Metab 2002;76:201-6.

152. Reynier P, Amati-Bonneau P, Verny C, Olichon A, Simard G, Guichet A, Bonnemains C, Malecaze F, Malinge MC, Pelletier JB, Calvas P, Dollfus $H$, Belenguer P, Malthiery $Y$, Lenaers G, Bonneau D. OPA3 gene mutations responsible for autosomal dominant optic atrophy and cataract. J Med Genet 2004;41e110.

153. Verny C, Amati-Bonneau P, Dubas F, Malthiery Y, Reynier P, Bonneau D. An OPA3 gene mutation is responsible for the disease associating optic atrophy and cataract with extrapyramidal signs. Revue Neurologique 2005;161:451-4.

154. Davies VJ, Powell KA, White KE, Yip W, Hogan V, Hollins AJ, Davies JR, Piechota M, Brownstein DG, Moat SJ, Nichols PP, Wride MA, Boulton ME, Votruba M. A missense mutation in the murine 0 pa3 gene models human Costeff syndrome. Brain 2008;131:368-80.

155. Leipnitz G, Seminotti B, Amaral AU, de Bortoli G, Solano A, Schuck PF, Wyse ATS, Wannmacher CMD, Latini A, Wajner M. Induction of oxidative stress by the metabolites accumulating in 3-methylglutaconic aciduria in cerebral cortex of young rats. Life Sci 2008;82:652-62.

156. Olichon A, Guillou E, Delettre C, Landes T, Arnaune-Pelloquin L, Emorine LJ, Mils V, Daloyau M, Hamel C, Amati-Bonneau P. Bonneau D, Reynier P, Lenaers G, Belenguer P. Mitochondrial dynamics and disease, OPA1. Biochim Biophys Acta Mol Cell Res 2006; 1763:500-9.

157. Ferre M, Amati-Bonneau P, Tourmen $Y$, Malthiery $Y$, Reynier P. eOPA1: an online database for OPA1 mutations. Hum Mutat 2005;25:423-8.

158. Pesch UEA, Leo-Kottler B, Mayor S, Jurklies B, Kellner U, Apfelstedt-Sylla E, Zrenner E, Alexander C, Wissinger B. OPA1 mutations in patients with autosomal dominant optic atrophy and evidence for semi-dominant inheritance. Hum Mol Genet 2001;10:1359-68.

159. Schimpf S, Schaich S, Wissinger B. Activation of cryptic splice sites is a frequent splicing defect mechanism caused by mutations in exon and intron sequences of the OPA1 gene. Hum Genet 2006;118:767-71.
160. Schimpf S, Fuhrmann N, Schaich S, Wissinger B. Comprehensive cDNA study and quantitative transcript analysis of mutant OPA1 transcripts containing premature termination codons. Hum Mutat 2008;29:106-12.

161. Marchbank NJ, Craig JE, Leek JP, Toohey M, Churchill AJ, Markham AF, Mackey DA, Toomes C, Inglehearn CF. Deletion of the OPA1 gene in a dominant optic atrophy family: evidence that haploinsufficiency is the cause of disease. J Med Genet 2002;39:e47.

162. Amati-Bonneau P, Valentino ML, Reynier P, Gallardo ME, Bornstein B, Boissiere A, Campos Y, Rivera H, de la Aleja JG, Carroccia R, lommarini L, Labauge P, FigarellaBranger D, Marcorelles P, Furby A, Beauvais K, Letournel F, Liguori R, La Morgia C Montagna P, Liguori M, Zanna C, Rugolo M, Cossarizza A, Wissinger B, Verny C, Schwarzenbacher R, Martin MA, Arenas J, Ayuso C, Garesse R, Lenaers G, Bonneau D, Carelli V. OPA1 mutations induce mitochondrial DNA instability and optic atrophy plus phenotypes. Brain 2008;131:338-51.

163. Ferraris S, Clark S, Garelli E, Davidzon G, Moore SA, Kardon RH, Bienstock RJ, Longley MJ, Mancuso M, Rios PG, Hirano M, Copeland WC, DiMauro S. Progressive external ophthalmoplegia and vision and hearing loss in a patient with mutations in POLG2 and OPA1. Arch Neurol 2008;65:125-31.

164. Hudson G, Amati-Bonneau P, Blakely EL, Stewart JD, He LP, Schaefer AM, Griffiths PG, Ahlqvist K, Suomalainen A, Reynier P, McFarland R, Turnbull DM, Chinnery PF, Taylor RW. Mutation of OPA1 causes dominant optic atrophy with external ophthalmoplegia, ataxia, deafness and multiple mitochondrial DNA deletions: a novel disorder of mtDNA maintenance. Brain 2008;131:329-37.

165. Aijaz S, Erskine L, Jeffery G, Bhattacharya SS, Votruba M. Developmental expression profile of the optic atrophy gene product: OPA1 is not localized exclusively in the mammalian retinal ganglion cell layer. Invest Ophthalmol Vis Sci 2004:45:1667-73

166. Pesch UEA, Fries JE, Bette S, Kalbacher H, Wissinger B, Alexander C, Kohler K OPA1, the disease gene for autosomal dominant optic atrophy, is specifically expressed in ganglion cells and intrinsic neurons of the retina. Invest Ophthalmol Vis Sci 2004:45:4217-25.

167. Ju WK, Misaka T, Kushnareva Y, Nakagomi S, Agarwal N, Kubo Y, Lipton SA Bossy-Wetzel E. OPA1 expression in the normal rat retina and optic nerve. J Comp Neurol 2005;488:1-10

168. Wang AG, Fann MJ, Yu HY, Yen MY. OPA1 expression in the human retina and optic nerve. Exp Eye Res 2006;83:1171-8.

169. Bette S, Schlaszus H, Wissinger B, Meyermann R, Mittelbronn M. OPA1, associated with autosomal dominant optic atrophy, is widely expressed in the human brain. Acta Neuropathol 2005;109:393-9.

170. Kamei S, Chen-Kuo-Chang M, Cazevieille C, Lenaers G, Olichon A, Belenguer $P$ Roussignol G, Renard N, Eybalin M, Michelin A, Delettre C, Brabet P, Hamel CP. Expression of the Opa1 mitochondrial protein in retinal ganglion cells: its downregulation causes aggregation of the mitochondrial network. Invest Ophthalmol Vis Sci 2005; 46:4288-94.

171. Guan KL, Farh L, Marshall TK, Deschenes RJ. Normal mitochondrial structure and genome maintenance in yeast requires the dynamin-like product of the Mgm1 gene. Curr Genet 1993:24:141-8

172. Wong ED, Wagner JA, Scott SV, Okreglak V, Holewinske TJ, Cassidy-Stone A, Nunnari J. The intramitochondrial dynamin-related GTPase, Mgm1p, is a component of a protein complex that mediates mitochondrial fusion. J Cell Biol 2003;160:303-11.

173. Praefcke GJK, McMahon HT. The dynamin superfamily: universal membrane tubulation and fission molecules? Nat Rev Mol Cell Biol 2004;5:133-47.

174. Chan DC. Mitochondrial fusion and fission in mammals. Annu Rev Cell Dev Biol 2006:22:79-99.

175. Olichon A, Landes T, Arnaune-Pelloquin L, Emorine LJ, Mils V, Guichet A, Delettre C. Hamel C, Amati-Bonneau P. Bonneau D, Reynier P, Lenaers G, Belenguer P. Effects of OPA1 mutations on mitochondrial morphology and apoptosis: relevance to ADOA pathogenesis. J Cell Physiol 2007:211:423-30.

176. Zanna C, Ghelli A, Porcelli AM, Karbowski M, Youle RJ, Schimpf S, Wissinger B, Pinti M, Cossarizza A, Vidoni S, Valentino ML, Rugolo M, Carelli V. OPA1 mutations associated with dominant optic atrophy impair oxidative phosphorylation and mitochondrial fusion. Brain 2008;131:352-67.

177. Chen H, Chan DC. Critical dependence of neurons on mitochondrial dynamics. Curr Opin Cell Biol 2006:18:453-9.

178. Chan DC. Mitochondrial dynamics in disease. N Engl J Med 2007;356:1707-9.

179. Chen H, McCaffery JM, Chan DC. Mitochondrial fusion protects against neurodegeneration in the cerebellum. Cell 2007;130:548-62.

180. Kanazawa T. The C. elegans Opa1 homologue EAT-3 is essential for resistance to free radicals. PLoS Genet 2008:4:e1000022.

181. Amati-Bonneau P, Guichet A, Olichon A, Chevrollier A, Viala F, Miot S, Ayuso C Odent S, Arrouet C, Verny C, Calmels MN, Simard G, Belenguer P, Wang J, Puel JL, Hamel C. Malthiery Y, Bonneau D, Lenaers G, Reynier P. OPA1 R445H mutation in optic atrophy associated with sensorineural deafness. Ann Neurol 2005;58:958-63.

182. Chevrollier A. Hereditary optic neuropathies share a common mitochondrial coupling defect. Ann Neurol 2008;63:794-8.

183. Lodi R, Tonon C, Valentino ML, lotti S, Clementi V, Malucelli E, Barboni P, Longanesi L, Schimpf S, Wissinger B, Baruzzi A, Barbiroli B, Carelli V. Deficit of in vivo mitochondrial ATP production in OPA1-related dominant optic atrophy. Ann Neurol 2004:56:719-23.

184. Cipolat S, Rudka T, Hartmann D, Costa V, Serneels L, Craessaerts K, Metzger K, Frezza C, Annaert W, D’Adamio L, Derks C, Dejaegere T, Pellegrini L, D’Hooge R, Scorrano L, De Strooper B. Mitochondrial rhomboid PARL regulates cytochrome c 
release during apoptosis via OPA1-dependent cristae remodeling. Cell 2006;126:163-75

185. Ishihara N, Fujita Y, Oka T, Mihara K. Regulation of mitochondrial morphology through proteolytic cleavage of OPA1. Embo J 2006;25:2966-77.

186. Griparic L, Kanazawa $T$, van der Bliek AM. Regulation of the mitochondrial dynamin-like protein Opa1 by proteolytic cleavage. J Cell Biol 2007:178:757-64.

187. Frezza C, Cipolat S, de Brito OM, Micaroni M, Beznoussenko GV, Rudka T, Bartoli D, Polishuck RS, Danial NN, De Strooper B, Scorrano L. OPA1 controls apoptotic cristae remodeling independently from mitochondrial fusion. Cell 2006;126:177-89.

188. Olichon A, Baricault L, Gas N, Guillou E, Valette A, Belenguer P, Lenaers G. Loss of OPA1 perturbates the mitochondrial inner membrane structure and integrity, leading to cytochrome c release and apoptosis. J Biol Chem 2003;278:7743-6.

189. Alavi MV, Bette S, Schimpf S, Schuettauf F, Schraermeyer U, Wehrl HF, Ruttiger L, Beck SC, Tonagel F, Pichler BJ, Knipper M, Peters T, Laufs J. Wissinger B. A splice site mutation in the murine Opa1 gene features pathology of autosomal dominant optic atrophy. Brain 2007;130:1029-42.

190. Davies VJ, Hollins AJ, Piechota MJ, Yip W, Davies JR, White KE, Nicols PP Boulton ME, Votruba M. Opa1 deficiency in a mouse model of autosomal dominant optic atrophy impairs mitochondrial morphology, optic nerve structure and visual function. Hum Mol Genet 2007;16:1307-18.

191. Amati-Bonneau P, Odent S, Derrien C, Pasquier L, Malthiery Y, Reynier P, Bonneau $\mathrm{D}$. The association of autosomal dominant optic atrophy and moderate deafness may be due to the R445H mutation in the OPA1 gene. Am J Ophthalmol 2003; 136:1170-1.

192. Li CM, Kosmorsky G, Zhang K, Katz BJ, Ge J, Traboulsi El. Optic atrophy and sensorineural hearing loss in a family caused by an R445H OPA1 mutation. Am J Med Genet Part A 2005:138A:208-11.

193. Liguori M. A phenotypic variation of dominant optic atrophy and deafness (ADOAD) due to a novel OPA1 mutation. J Neurol 2008;255:127-9.

194. Verny C. Multiple sclerosis-like disorder in OPA1-related autosomal dominant optic atrophy. Neurology 2008;70:1152-3

195. Stewart JD, Hudson G, Yu-Wai-Man P, Horvath R, Maddison P, Wright A, Blakely EL, He LP, Griffiths PG, Turnbull DM, Taylor RW, Chinnery PF. OPA1 in multiple mitochondrial DNA deletion disorders. Neurology 2008;71:1829-31.

196. Toomes C, Marchbank NJ, Mackey DA, Craig JE, Newbury-Ecob RA, Bennett CP, Vize CJ, Desai SP, Black GCM, Patel N, Teimory M, Markham AF, Inglehearn CF, Churchill AJ. Spectrum, frequency and penetrance of OPA1 mutations in dominant optic atrophy. Hum Mol Genet 2001:10:1369-78.

197. Thiselton DL, Alexander C, Taanman JW, Brooks S, Rosenberg T, Eiberg H, Andreasson S, Van Regemorter N, Munier FL, Moore AT, Bhattacharya SS, Votruba M. A comprehensive survey of mutations in the OPA1 gene in patients with autosomal dominant optic atrophy. Invest Ophthalmol Vis Sci 2002;43:1715-24.

198. Carroll WM, Kriss A, Baraitser M, Barrett G, Halliday AM. The incidence and nature of visual pathway involvement in Friedreich's ataxia. A clinical and visual evoked potential study of 22 patients. Brain 1980;103:413-34.

199. Livingstone IR, Mastaglia FL, Edis R, Howe JW. Visual involvement in Friedreich's ataxia and hereditary spastic ataxia. A clinical and visual evoked response study. Arch Neurol 1981;38:75-9.

200. Chalmers RM, Riordan-Eva P, Wood NW. Autosomal recessive inheritance of hereditary motor and sensory neuropathy with optic atrophy. J Neurol Neurosurg Psychiatry 1997:62:385-7.

201. Zuchner S, De Jonghe P, Jordanova A, Claeys KG, Guergueltcheva V, Cherninkova S, Hamilton SR, Van Stavern G, Krajewski KM, Stajich J, Tournev I, Verhoeven K, Langerhorst CT, de Visser M, Baas F, Bird T, Timmerman V, Shy M, Vance JM. Axonal neuropathy with optic atrophy is caused by mutations in mitofusin 2. Ann Neurol 2006:59:276-81.

202. Livingstone IR, Mastaglia FL, Edis R, Howe JW. Pattern visual evoked responses in hereditary spastic paraplegia. J Neurol Neurosurg Psychiatry 1981;44:176-8.

203. Miyama S, Arimoto K, Kimiya S, Miyama S. Complicated hereditary spastic paraplegia with peripheral neuropathy, optic atrophy and mental retardation. Neuropediatrics 2000:31:214-7.

204. Makhoul J, Cordonnier M, Van Nechel C. Optic neuropathy in Strumpell-Lorrain disease: presentation of a clinical case and literature review. Bull Soc Belge Ophtalmol 2002;286:9-14.

205. Bunce C, Wormald R. Leading causes of certification for blindness and partial sight in England \& Wales. Bmc Public Health 2006:6.

206. Wiggs JL. Genetic etiologies of glaucoma. Arch Ophthalmol 2007;125:30-7

207. Buono LM, Foroozan R, Sergott RC, Savino PJ. Is normal tension glaucoma actually an unrecognized hereditary optic neuropathy? New evidence from genetic analysis. Curr Opin Ophthalmol 2002;13:362-70.

208. Aung T, Ocaka L, Ebenezer ND, Morris AG, Krawczak M, Thiselton DL, Alexander C, Votruba M, Brice G, Child AH, Francis PJ, Hitchings RA, Lehmann OJ, Bhattacharya SS. A major marker for normal tension glaucoma: association with polymorphisms in the OPA1 gene. Hum Genet 2002;110:52-6.

209. Powell B, Toomes C, Scott S, Yeung A, Marchbank N, Spry P, Lumb R, Inglehearn C, Churchill A. Polymorphisms in OPA1 are associated with normal tension glaucoma. Mol Vis 2003;9:460-4.

210. Mabuchi F, Tang S, Kashiwagi K, Yamagata Z, lijima H, Tsukahara S. The OPA1 gene polymorphism is associated with normal tension and high tension glaucoma. Am J Ophthalmol 2007;143:125-30.

211. Abu-Amero KK, Morales J, Bosley TM. Mitochondrial abnormalities in patients with primary open-angle glaucoma. Invest Ophthalmol Vis Sci 2006;47:2533-41.
212. Andrews RM, Griffiths PG, Johnson MA, Turnbull DM. Histochemical localisation of mitochondrial enzyme activity in human optic nerve and retina. $\mathrm{Br} \mathrm{J} \mathrm{Ophthalmol}$ 1999;83:231-5

213. Yu Wai Man CY, Chinnery PF, Griffiths PG. Optic neuropathies - importance of spatial distribution of mitochondria as well as function. Med Hypotheses 2005;65:1038-42

214. Bristow EA, Griffiths PG, Andrews RM, Johnson MA, Turnbull DM. The distribution of mitochondrial activity in relation to optic nerve structure. Arch Ophthalmol 2002;120:791-6.

215. Barron MJ, Griffiths P, Turnbull DM, Bates D, Nichols P. The distributions of mitochondria and sodium channels reflect the specific energy requirements and conduction properties of the human optic nerve head. $\mathrm{Br} \mathrm{J}$ Ophthalmol 2004:88:286-90.

216. Baloh RH, Schmidt RE, Pestronk A, Milbrandt J. Altered axonal mitochondrial transport in the pathogenesis of Charcot-Marie-Tooth disease from mitofusin 2 mutations. J Neurosci 2007;27:422-30.

217. Detmer SA, Velde CV, Cleveland DW, Chan DC. Hindlimb gait defects due to motor axon loss and reduced distal muscles in a transgenic mouse model of CharcotMarie-Tooth type 2A. Hum Mol Genet 2008;17:367-75.

218. Ferreirinha F, Quattrini A, Pirozzi M, Valsecchi V, Dina G, Broccoli V, Auricchio A Piemonte F, Tozzi G, Gaeta L, Casari G, Ballabio A, Rugarli El. Axonal degeneration in paraplegin-deficient mice is associated with abnormal mitochondria and impairment of axonal transport. J Clin Invest 2004:113:231-42.

219. Rugarli El, Langer T. Translating m-AAA protease function in mitochondria to hereditary spastic paraplegia. Trends Mol Med 2006;12:262-9.

220. Huoponen K, Vilkki J, Aula P, Nikoskelainen EK, Savontaus ML. A new mtDNA mutation associated with Leber hereditary optic neuroretinopathy. Am J Hum Genet 1991:48:1147-53

221. Howell N, Bindoff LA, McCullough DA, Kubacka I, Poulton J, Mackey D, Taylor L, Turnbull DM. Leber hereditary optic neuropathy: identification of the same mitochondrial ND1 mutation in six pedigrees. Am J Hum Genet 1991;49:939-50.

222. Johns DR, Neufeld MJ, Park RD. An ND-6 mitochondrial DNA mutation associated with Leber hereditary optic neuropathy. Biochem Biophys Res Commun 1992:187:1551-7

223. Valentino ML, Barboni P, Ghelli A, Bucchi L, Rengo C, Achilli A, Torroni A, Lugares A, Lodi R, Barbiroli B, Dotti M, Federico A, Baruzzi A, Carelli V. The ND1 gene of complex I is a mutational hot spot for Leber's hereditary optic neuropathy. Ann Neurol 2004;56:631-41.

224. Kim JY, Hwang JM, Park SS. Mitochondrial DNA C4171A/ND1 is a novel primary causative mutation of Leber's hereditary optic neuropathy with a good prognosis. Ann Neurol 2002;51:630-4.

225. Leo-Kottler B, Luberichs J, Besch D, Christ-Adler M, Fauser S. Leber's hereditary optic neuropathy: clinical and molecular genetic results in a patient with a point mutation at np T11253C (isoleucine to threonine) in the ND4 gene and spontaneous recovery. Graefes Arch Clin Exp Ophthalmol 2002;240:758-64.

226. Brown MD, Starikovskaya E, Derbeneva 0, Hosseini S, Allen JC, Mikhailovskaya IE, Sukernik RI, Wallace DC. The role of mtDNA background in disease expression: a new primary LHON mutation associated with Western Eurasian haplogroup J. Hum Genet 2002;110:130-8

227. Mayorov V, Biousse V, Newman NJ, Brown MD. The role of the ND5 gene in LHON: characterization of a new, heteroplasmic LHON mutation. Ann Neurol 2005;58:807-11

228. Howell N, Halvorson S, Burns J, McCullough DA, Paulton J. When does bilateral optic atrophy become Leber hereditary optic neuropathy? Am J Hum Genet 1993:53:959-63.

229. Besch D, Leo-Kottler B, Zrenner E, Wissinger B. Leber's hereditary optic neuropathy: clinical and molecular genetic findings in a patient with a new mutation in the ND6 gene. Graefes Arch Clin Exp Ophthalmol 1999;237:745-52.

230. Zhadanov SI, Atamanov WV, Zhadanov NI, Oleinikov OV, Osipova LP, Schurr TG. A novel mtDNA ND6 gene mutation associated with LHON in a Caucasian family. Biochem Biophys Res Commun 2005:332:1115-21.

231. Howell N, Bogolin C, Jamieson R, Marenda DR, Mackey DA. mtDNA mutations that cause optic neuropathy: how do we know? Am J Hum Genet 1998;62:196-202.

232. Chinnery PF, Brown DT, Andrews RM, Singh-Kler R, Riordan-Eva P, Lindley J. Applegarth DA, Turnbull DM, Howell N. The mitochondrial ND6 gene is a hot spot for mutations that cause Leber's hereditary optic neuropathy. Brain 2001:124:209-18.

233. Wissinger B, Besch D, Baumann B, Fauser S, Christ-Adler M, Jurklies B, Zrenner E, Leo-Kottler B. Mutation analysis of the ND6 gene in patients with Lebers hereditary optic neuropathy. Biochem Biophys Res Commun 1997:234:511-5.

234. Fauser S, Leo-Kottler B, Besch D, Luberichs J. Confirmation of the 14568 mutation in the mitochondrial ND6 gene as causative in Leber's hereditary optic neuropathy. Ophthalmic Genet 2002:23:191-7.

235. Parker WD Jr, Oley CA, Parks JK. A defect in mitochondrial electron-transport activity (NADH-coenzyme 0 oxidoreductase) in Leber's hereditary optic neuropathy. N Engl J Med 1989;320:1331-3.

236. Majander A, Huoponen K, Savontaus ML, Nikoskelainen E, Wikstrom M. Electron transfer properties of NADH:ubiquinone reductase in the ND1/3460 and the ND4/ 11778 mutations of the Leber hereditary optic neuroretinopathy (LHON). FEBS Lett 1991;292:289-92.

237. Larsson NG, Andersen 0, Holme E, Oldfors A, Wahlstrom J. Leber's hereditary optic neuropathy and complex I deficiency in muscle. Ann Neurol 1991;30:701-8.

238. Smith PR, Cooper JM, Govan GG, Harding AE, Schapira AH. Platelet mitochondrial function in Leber's hereditary optic neuropathy. J Neurol Sci 1994;122:80-3. 
239. Degli Esposti M, Carelli V, Ghelli A, Ratta M, Crimi M, Sangiorgi S, Montagna P, Lenaz G, Lugaresi E, Cortelli P. Functional alterations of the mitochondrially encoded ND4 subunit associated with Leber's hereditary optic neuropathy. FEBS Lett 1994:352:375-9.

240. Cock HR, Cooper JM, Schapira AH. The 14484 ND6 mtDNA mutation in Leber hereditary optic neuropathy does not affect fibroblast complex I activity [letter]. Am J Hum Genet 1995; 57:1501-2.

241. Oostra RJ, Van Galen MJ, Bolhuis PA, Bleeker-Wagemakers EM, Van den Bogert C. The mitochondrial DNA mutation ND6*14,484C associated with Leber hereditary optic neuropathy, leads to deficiency of complex I of the respiratory chain. Biochem Biophys Res Commun 1995;215:1001-5.

242. Montagna P, Plazzi G, Cortelli P, Carelli V, Lugaresi E, Barboni P, Fiocchi M. Abnormal lactate after effort in healthy carriers of Leber's hereditary optic neuropathy [letter]. J Neurol Neurosurg Psychiatry 1995;58:640-1.

243. Majander A, Finel M, Savontaus ML, Nikoskelainen E, Wikstrom M. Catalytic activity of complex I in cell lines that possess replacement mutations in the ND genes in Leber's hereditary optic neuropathy. Eur J Biochem 1996;239:201-7.

244. Hofhaus G, Johns DR, Hurko 0, Attardi G, Chomyn A. Respiration and growth defects in transmitochondrial cell lines carrying the 11778 mutation associated with Leber's hereditary optic neuropathy. J Biol Chem 1996;271:13155-61.

245. Carelli V, Ghelli A, Ratta M, Bacchilega E, Sangiorgi S, Mancini R, Leuzzi V, Cortelli P, Montagna P, Lugaresi E, Degli Esposti M. Leber's hereditary optic neuropathy: biochemical effect of 11778/ND4 and 3460/ND1 mutations and correlation with the mitochondrial genotype. Neurology 1997;48:1623-32.

246. Cock HR, Tabrizi SJ, Cooper JM, Schapira AH. The influence of nuclear background on the biochemical expression of 3460 Leber's hereditary optic neuropathy. Ann Neurol 1998;44:187-93

247. Cock HR, Cooper JM, Schapira AH. Functional consequences of the 3460-bp mitochondrial DNA mutation associated with Leber's hereditary optic neuropathy. J Neurol Sci 1999;165:10-7.
248. Brown MD, Trounce IA, Jun AS, Allen JC, Wallace DC. Functional analysis of lymphoblast and cybrid mitochondria containing the 3460, 11778, or 14484 Leber's hereditary optic neuropathy mitochondrial DNA mutation. J Biol Chem 2000;275:39831-6.

249. Baracca A, Solaini G, Sgarbi G, Lenaz G, Baruzzi A, Schapira AH, Martinuzzi A, Carelli V. Severe impairment of complex I-driven adenosine triphosphate synthesis in Leber hereditary optic neuropathy cybrids. Arch Neurol 2005; 62:730-6.

250. Kerrison JB, Arnould VJ, Sallum JMF, Vagefi MR, Barmada MM, Li YY, Zhu DP, Maumenee $\mathrm{IH}$. Genetic heterogeneity of dominant optic atrophy, Kjer type Identification of a second locus on chromosome 18q12.2-12.3. Arch Ophthalmol 1999;117:805-10.

251. Barbet F, Hakiki S, Orssaud C, Gerber S, Perrault I, Hanein S, Ducroq D, Dufier JL, Munnich A, Kaplan J, Rozet JM. A third locus for dominant optic atrophy on chromosome 22q. J Med Genet 2005;42:e1.

252. Carelli V, Schimpf S, Valentino ML, Fuhrmann N, Papke M, Schaich S, Tippmann S, Baumann B, Barboni P, Ghelli A, Bucchi L, Lodi R, Barbiroli B, Liguori R, Carroccia R, Villanova M, Montagna P, Baruzzi A, Wissinger B. Dominant optic atrophy (DOA) and sensorineural hearing loss: clinical, biochemical, spectroscopic and molecular genetic study of a large Italian pedigree linked to a new locus an chromosome 16. Neurology 2007;68:A42.

253. Puccio H, Koenig M. Friedreich ataxia: a paradigm for mitochondrial diseases. Curr Opin Genet Dev 2002;12:272-7.

254. Rouault TA, Tong WH. Iron-sulphur cluster biogenesis and mitochondrial iron homeostasis. Nat Rev Mol Cell Biol 2005;6:345-51.

255. Zuchner S, Vance JM. Mechanisms of disease: a molecular genetic update on hereditary axonal neuropathies. Nat Clin Pract Neurol 2006;2:45-53.

256. Casari G, Rugarli E. Molecular basis of inherited spastic paraplegias. Curr Opin Genet Dev 2001;11:336-42.

\section{Drug and Therapeutics Bulletin (DTB)}

\section{Your key source of unbiased, independent advice}

For over 45 years DTB has been an independent, indispensable part of evidence-based clinical practice. DTB offers healthcare professionals detailed assessment of, and practical advice on, individual medicines and other treatments, groups of treatment and the overall management of disease.

DTB is now also available online at http://dtb.bmj.com:

- browse or search all DTB content from the latest issue back to 1994

- email alerting, sophisticated searching, RSS feeds and full text links from cited references

- interactive services such as My Folders for quick access to articles that you have viewed previously and My Searches to save and re-use useful searches

- comment online on any DTB article

To subscribe, or for further information, please visit http://dtb.bmj.com 
5. Watson $\mathbf{P}$, Lynch HT. Cancer risk in mismatch repair gene mutation carriers. Fam Cancer 2001;1:57-60.

6. Lynch HT, de la Chapelle A. Hereditary colorectal cancer. N Engl J Med 2003:348:919-32.

7. Alarcon F, Lasset C, Carayol J, Bonadona V, Perdry H, Desseigne F, Wang 2 , Bonaiti-Pellie C. Estimating cancer risk in HNPCC by the GRL method. Eur J Hum Genet 2007;15:831-6.

8. Fostira F, Thodi G, Konstantopoulou I, Sandaltzopoulos R, Yannoukakos D. Hereditary cancer syndromes. J Buon 2007:12(Suppl 1):S13-22.

9. Jaeger E, Webb E, Howarth K, Carvajal-Carmona L, Rowan A, Broderick P, Walther A, Spain S, Pittman A, Kemp Z, Sullivan K, Heinimann K, Lubbe S, Domingo E, Barclay E, Martin L, Gorman M, Chandler I, Vijayakrishnan J, Wood W, Papaemmanuil E, Penegar S, Qureshi M, Farrington S, Tenesa A, Cazier JB, Kerr D, Gray R, Peto J, Dunlop M, Campbell H, Thomas H, Houlston R, Tomlinson I. Common genetic variants at the CRAC1 (HMPS) locus on chromosome 15q13.3 influence colorectal cancer risk. Nat Genet 2008;40:26-8

10. Broderick P, Carvajal-Carmona L, Pittman AM, Webb E, Howarth K, Rowan A Lubbe S, Spain S, Sullivan K, Fielding S, Jaeger E, Vijayakrishnan J, Kemp Z, Gorman M, Chandler I, Papaemmanuil E, Penegar S, Wood W, Sellick G, Oureshi M, Teixeira A, Domingo E, Barclay E, Martin L, Sieber O, Kerr D, Gray R, Peto J Cazier JB, Tomlinson I, Houlston RS. A genome-wide association study shows that common alleles of SMAD7 influence colorectal cancer risk. Nat Genet 2007:39:1315-17.

11. Tenesa A, Farrington SM, Prendergast JG, Porteous ME, Walker M, Haq N, Barnetson RA, Theodoratou E, Cetnarskyj R, Cartwright N, Semple C, Clark AJ, Reid FJ, Smith LA, Kavoussanakis K, Koessler T, Pharoah PD, Buch S, Schafmayer C, Tepel J, Schreiber S, Volzke H, Schmidt CO, Hampe J, Chang-Claude J, Hoffmeister M, Brenner H, Wilkening S, Canzian F, Capella G, Moreno V, Deary IJ Starr JM, Tomlinson IP, Kemp Z, Howarth K, Carvajal-Carmona L, Webb E, Broderick P, Vijayakrishnan J, Houlston RS, Rennert G, Ballinger D, Rozek L, Gruber SB, Matsuda K, Kidokoro T, Nakamura Y, Zanke BW, Greenwood CM Rangrej J, Kustra R, Montpetit A, Hudson TJ, Gallinger S, Campbell H, Dunlop MG. Genome-wide association scan identifies a colorectal cancer susceptibility locus on 11q23 and replicates risk loci at 8q24 and 18q21. Nat Genet 2008;40:631-7.

12. Tomlinson IP, Webb E, Carvajal-Carmona L, Broderick P, Howarth K, Pittman AM, Spain S, Lubbe S, Walther A, Sullivan K, Jaeger E, Fielding S, Rowan A Vijayakrishnan J, Domingo E, Chandler I, Kemp Z, Qureshi M, Farrington SM, Tenesa A, Prendergast JG, Barnetson RA, Penegar S, Barclay E, Wood W, Martin L, Gorman M, Thomas H, Peto J, Bishop DT, Gray R, Maher ER, Lucassen A, Kerr D, Evans DG, Schafmayer C, Buch S, Volzke H, Hampe J, Schreiber S, John U, Koessler T, Pharoah P, van Wezel T, Morreau H, Wijnen JT, Hopper JL, Southey MC, Giles GG, Severi G, Castellvi-Bel S, Ruiz-Ponte C, Carracedo A, Castells A, Forsti A, Hemminki K, Vodicka P, Naccarati A, Lipton L, Ho JW, Cheng KK, Sham PC, Luk J,
Agundez JA, Ladero JM, de la Hoya M, Caldes T, Nïttymaki I, Tuupanen S, Karhu A Aaltonen L, Cazier JB, Campbell H, Dunlop MG, Houlston RS. A genome-wide association study identifies colorectal cancer susceptibility loci on chromosomes 10p14 and 8q23.3. Nat Genet 2008:40:623-30.

13. Wijnen JT, Brohet RM, van Eijk R, Jagmohan-Changur S, Middeldorp A, Tops CM van Puijenbroek M, Ausems MG, Gomez Garcia E, Hes FJ, Hoogerbrugge N, Menko FH, van Os TA, Sijmons RH, Verhoef S, Wagner A, Nagengast FM, Kleibeuker JH, Devilee P, Morreau H, Goldgar D, Tomlinson IP, Houlston RS, van Wezel T, Vasen HF. Chromosome 8q23.3 and 11q23.1 variants modify colorecta cancer risk in Lynch syndrome. Gastroenterology 2009;136:131-7.

14. Miller SA, Dykes DD, Polesky HF. A simple salting out procedure for extracting DNA from human nucleated cells. Nucleic Acids Res 1988:16:1215.

15. Dong Z, Zhang JT. Initiation factor elF3 and regulation of mRNA translation, cell growth, and cancer. Crit Rev Oncol Hematol 2006;59:169-80.

16. Okamoto H, Yasui $\mathrm{K}$, Zhao C, Arii S, Inazawa J. PTK2 and EIF3S3 genes may be amplification targets at $8 \mathrm{q} 23-\mathrm{q} 24$ and are associated with large hepatocellular carcinomas. Hepatology 2003:38:1242-9.

17. Savinainen KJ, Linja MJ, Saramaki OR, Tammela TL, Chang GT, Brinkmann AO, Visakorpi T. Expression and copy number analysis of TRPS1, EIF3S3 and MYC genes in breast and prostate cancer. Br J Cancer 2004;90:1041-6.

18. Lohmueller KE, Mauney MM, Reich D, Braverman JM. Variants associated with common disease are not unusually differentiated in frequency across populations. Am J Hum Genet 2006;78:130-6.

19. Bandipalliam P. Variability in the clinical phenotype among families with HNPCC-the potential importance of the location of the mutation in the gene. Int J Cancer 2007;120:2275-7; author reply 8.

20. Jones JS, Chi X, Gu X, Lynch PM, Amos Cl, Frazier ML. p53 polymorphism and age of onset of hereditary nonpolyposis colorectal cancer in a Caucasian population. Clin Cancer Res 2004;10:5845-9.

21. Talseth BA, Meldrum C, Suchy J, Kurzawski G, Lubinski J, Scott RJ. Age of diagnosis of colorectal cancer in HNPCC patients is more complex than that predicted by R72P polymorphism in TP53. Int J Cancer 2006;118:2479-84.

22. Talseth BA, Meldrum C, Suchy J, Kurzawski G, Lubinski J, Scott RJ. Aurora-A and Cyclin D1 polymorphism and the age of onset of colorectal cancer in Hereditary Nonpolyposis Colorectal Cancer. Int J Cancer 2008;122:1273-7.

23. Kruger S, Engel C, Bier A, Mangold E, Pagenstecher C, Doeberitz MK, Holinski-Fede E, Moeslein G, Keller G, Kunstmann E, Friedl W, Plaschke J, Ruschoff J, Schackert HK. Absence of association between cyclin D1 (CCND1) G870A polymorphism and age of onset in hereditary nonpolyposis colorectal cancer. Cancer Lett 2006;236:191-7

24. Chen J, Sen S, Amos Cl, Wei C, Jones JS, Lynch P, Frazier ML. Association between Aurora-A kinase polymorphisms and age of onset of hereditary nonpolyposis colorectal cancer in a Caucasian population. Mol Carcinog 2007;46:249-56.

\section{Correction}

P Yu-Wai-Man, P G Griffiths, G Hudson, et al. Inherited mitochondrial optic neuropathies. J Med Genet 2009;46:145-58. Errors appeared in the first paragraph of the 'Clinical features' section in this paper. The correct paragraph should read as follows:

'The clinical features of DOA (OMIM 165500) were first described in one British family by Batten in $1896^{119} 120$; the phenotype was further clarified by Kjer in his extensive study of Danish families in the 1950's, ${ }^{119} 120$ distinguishing it from LHON with which the disease was often confused. The prevalence of DOA is not well established and robust estimates based on molecular confirmation are not available, although a historical figure of 1 in 50,000 among Caucasians is often quoted in the literature. ${ }^{121}$ It is thought to be the most common inherited optic neuropathy in Denmark with a population frequency of 1 in 12,000, and this much higher prevalence has been linked to a mutational founder event. ${ }^{122}$, 